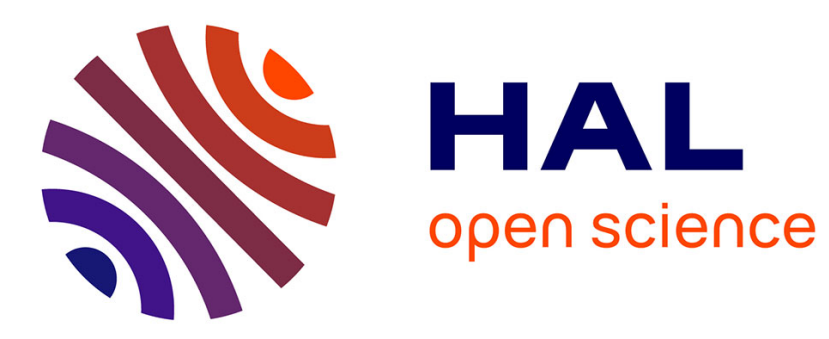

\title{
Polish Households' Behavior in the Regular and Informal Economies
}

François Gardes, Christophe Starzec

\section{To cite this version:}

François Gardes, Christophe Starzec. Polish Households' Behavior in the Regular and Informal Economies. Revue Economique, 2009, 60 (5), pp.1181-1210. 10.3917/reco.605.1181 . halshs00449447

\section{HAL Id: halshs-00449447 https://shs.hal.science/halshs-00449447}

Submitted on 21 Jan 2010

HAL is a multi-disciplinary open access archive for the deposit and dissemination of scientific research documents, whether they are published or not. The documents may come from teaching and research institutions in France or abroad, or from public or private research centers.
L'archive ouverte pluridisciplinaire HAL, est destinée au dépôt et à la diffusion de documents scientifiques de niveau recherche, publiés ou non, émanant des établissements d'enseignement et de recherche français ou étrangers, des laboratoires publics ou privés. 


\title{
Polish Households Between Regular and Informal Economy ${ }^{1}$
}

\author{
François Gardes, Paris School of Economics, Université Paris I Panthéon-Sorbonne* \\ Christophe Starzec, CNRS, Université Paris I Panthéon-Sorbonne*,
}

\begin{abstract}
The paper analyzes characteristics of the informal economy in Poland in the context of transition using a specific survey carried out in the frame of the classic Labor Force Survey 1995 by the Polish National Statistical office (GUS). The participation probabilities of three types of informal activities (working, buying and hiring) are discussed. Their interdependencies are discussed the hypothesis of the network or neighborhood effects. The impact of the household's participation on informal markets on its regular consumption is estimated by imputing the informal activity probabilities to the consumption surveys and panel. Then, the specific consumption profiles of participants in the informal market can be identified. This participation does influence significantly more than half of the household's expenditure groups. Moreover, the participants of the informal economy distinguish themselves by the higher individual full prices (integrating non monetary constraints and resources).
\end{abstract}

Key words: Informal economy, Consumer behavior, Cross-section-panel estimation JEL codes: D12 H26 J49 C31 C32

\section{Introduction.}

During a transition period, such as experienced by Poland since the liberalization of foreign and domestic markets on the $1^{\text {st }}$ January 1990, the old type informal market activities have gradually disappeared as the official markets got stronger, but simultaneously new informal activities were created by the appearance of constraints on households or firms. For instance, subsistence constraints are likely to have appeared for households in 1989 and 1990, which might have obliged households to seek new sources of revenue and to minimize food prices by intervening on black markets. The gradual definition of the limits and organization of official markets can also have created new legal constraints for firms, which may use unofficial channels to weaken their transaction costs. It is particularly important to analyze the behavior of households on informal markets during this period, as a mean to predict whether the informal economy will disappear soon after a first rise during a transition, or persist as a permanent structure (see Dupaigne-Hénin, 2001). Three reasons may drive households towards the black market: first the search for cheaper commodities in monetary terms. Second, rationing (this is essentially the same as the first cause, commodities being cheaper on the black market considering that the sum the monetary and the virtual prices are arising from constraints and non monetary resources. Third, the participation on one side of the informal economy, for instance by working unofficially, may create social interactions which lowers the cost of other unofficial activities, for instance by buying goods on the black market (see Fortin-Lacroix-Montmarquette, 2000). Therefore, by considering both the participation of the household on the informal markets and its official labor supply and consumption, we are able to answer two questions. First, - does participation in various informal market activities is interdependent giving rise to a multiplier effect? -question posed by Fortin-Lacroix-Montmarquette (2000) for working and buying activities. Second - is the

\footnotetext{
* Centre d'Economie de la Sorbonne, 106-112, Bd. De l'Hôpital, 75014 Paris, France

${ }^{1}$ Thanks are due to the Polish Statistical Office for giving us the opportunity to use the Labor and Budget surveys and for Claude Montmarquette for his comments.
} 
informal consumption driven mainly by a minimizing behavior when households are looking for smaller monetary prices and minimizing the risk of intervening on black markets, or rather by the appearance of subsistence constraints due to the transition? In the last case, informal markets would disappear rapidly with these transitory subsistence constraints faced by households during the transition.

This paper presents also some essential facts on the informal markets in Poland during the transition and proposes the statistical matching method to measure the income effect of informal activities on regular expenditures. In section 1 we present some historical and methodological comments how the hidden economy was measured in Poland on macro and micro level during the transition period. In section 2, we define and estimate the participation probabilities including several types of informal economic activities: working, buying consumption goods and services or unregistered hiring. We analyse also the socio economic profiles of the participating households and interactions between different types informal activities. Our data source in this part is an original large scale informal economy survey conducted together with classic Labour Force Survey (Extended LFS) in Poland in 1995 (see appendix 2 for details). In the section 3 we estimate the impact of the informal markets participation probabilities on the regular consumption patterns using the extended LFS survey matched statistically with the1995 Household Budget Survey (HBS) and with the consumption panel issued from 1994-1996 time series of HBS(see appendix 2 for details). The specific consumption behavior characteristics of informal markets participants are analyzed by estimating the cross section and panel Almost Ideal DS-QAIDS models for the 1994-1996 period.

\section{Measuring the determinants and effects of informal market participations in the transition context}

Informal economy is a natural market reaction in presence of governmental (or institutional) interventions and regulations (Fortin 2002). In the case non fully market regulated economy (like in the case of centrally planned economies and to less extent transition countries) different types of rationing can be also source of the presence of strong informal sector. The economic agents try to avoid the implied constraints or extra costs by different types of participation in the informal economy.. Thus, the size and evolution of the informal sector depends on the character and weight of the state or institutional restrictions.

Comparing the size of informal economy size among different types of countries (developed, developing and countries in transition) using the same methodology (DYMIMIC macroeconomic model, Schneider (2007)) gives an idea of the relative importance of informal markets in various countries in the world with respect to their economic status. The transition countries average (39\% of PIB) is higher than in the most developed countries (14\%) but lower than in the developing countries $(42 \%)$. Among transition countries there is also a great heterogeneity. Poland's estimated share of informal economy in 2004/2005 is of $27 \%$ of the GDP below the average for all transition countries but above the Central European transition countries (Hungary (25\%), Slovak Republic(18\%), Czech Republic(18\%),

In Poland, like in other transition countries the informal economy has always existed, but its character and nature has changed dramatically during the transition period.

In the pre-transition period the formal-informal duality of economy was based mainly on multiple economic disequilibria resulting with a coexistence of generalized rationing with administered prices and almost free, informal market sectors with equilibrium prices for the 
same goods and services. The specific role was played by dual (informal) foreign currencies market (essentially dollar) as a link between supply constrained official market and unconstrained consumption market integrating the foreign currency regulations. . The time use (queuing) was another equilibrium factor with informal sharing of work time between private and enterprise use. The labor market was constrained on the demand side by quasi permanent workforce shortage for employers generating various forms of formal and informal adjustments like multi-employment situations for employees. The peculiar characteristics of informal markets under centrally planned Polish economy are described in detail in Starzec 1983, and explained in the frame of a disequilibrium model in Charemza $(1982,1990)$.

The transition from centrally planned to the market economy changed the character and nature of disequilibria and constraints generating the new forms of formal-informal duality in economy. Vanishing shortages on good and services markets are replaced by the new disequilibria especially on labor market with appearing unemployment with specific social protection counterpart (contribution and benefits). At the same time the liberalization of the economy, growing rapidly private sector was accompanied by large scale public finance reforms. The most important ones were the introduction of the progressive income tax, of the Value Added Tax (VAT), the individualization of social contributions and the old age pension reform. These changes created the new conditions for informal economy development, similar to those observed in traditional market economies. The opening of borders expanded considerably the informal international commerce activities (smuggling) and informal work migration. (see CASE, 2007). Thus, the most important effect of the transition from administrated economy of shortage to market economy with state regulation was a shift from consumption constrained to employment constrained situations with corresponding informal market behaviors. The transformation of informal markets was similar in several central European countries (Hungary, Czech Republic, Slovakia, but they differ for Russia (Kurkchiyan, Marina. 2000) and the former Soviet Union Republics where both pre-transition and post transition situations are institutionally and politically more specific and extremely heterogeneous (for Georgia for example see Bernabè, Stampini (2008)). The Polish particularity when compared to other Central European countries is related to the peculiar situation of agricultural sector both before and during the transition. Under centrally planned economy Poland is characterized by a relatively open economy and the presence of a very large $(90 \%)$ private sector in agriculture. During the transition period agriculture became potentially the most important part of informal labour market because of its high unemployment situation (GUS 1996) and the properties of the tax regime (lump sum taxation) .

Several sources of information must often be combined to obtain the most plausible image of the informal market reality. The macroeconomic evaluation methods try to correct the PIB aggregates for unregistered activities (Schneider 2007) whereas microeconomic approaches try to correct the individual income and expenditure distribution for the informal markets participation effects. Moreover, the microeconomic approach is essentially oriented to the question of cost-benefit utility maximation problem of tax evasion (Cowell,1985,1990) and more generally to the individual's economic and social reasons to participate in informal markets.

The classic micro-economic question of the trade off between participating on the formal or informal labour markets was formalized by Fortin, Lacroix (1992) in a structural model maximizing the individual's expected utility. However, the hidden nature and resulting lack of specific individual information makes very complex the estimation of a structural model. Most of econometric applications use its reduced form. 
Another difficulty is taking into account the risks of control and penalty costs or moral stigma evaluation for informal market participants in presence of active policies against underground activities. Fortin et al, 2004 discussed this problem and proposed an econometric model for informal market participation in this context.

Similarly the role of social interactions (Mansky, 2000), network effects or neighborhood effects ((Fortin et al 2002) on the informal activities are discussed in the literature but treated with many difficulties in empirical research because of identification problems and the lack of the specific data. More recent work on social interactions' role uses experimental data (Fortin et al 2007) with somewhat debatable empirical results because they are based on artificially composed groups of tax payers, and are difficult to extrapolate to the entire population.

Our approach is based on the same micro-economic background analyzing the causes and interactions between different informal behaviours. We analyse the informal market participation decisions taking the advantage of an original survey specifically devoted to informal activities study conducted in Poland in 1995 during the transition period (see GUS,1996). In particular we analyse the differences and links between various types of underground activities (buying, hiring and working) and discuss the existence of network effects (Section 1). Then we propose an original method to investigate the links between the consumption behaviour and informal market participation based on the statistically matched data on consumption and on informal activities (Section 2). This analysis allows the identification of the specific consumption patterns of informal market participants.

\subsection{General characteristics of informal markets participation in Poland in $1995^{2}$}

\section{Informal work}

In transition context the central question was analyzing informal work patterns in Poland as a dysfunction of the labor market, but also as a collateral phenomenon of unemployment and tax evasion. How do the people explain the reasons of participating in the informal labour market? (table1). In 1995 the most of them (63\%) indicate insufficient incomes or inability to find an official job (39\%). Too high taxes were responsible for almost $25 \%$ of moonlighters but only $10 \%$ were fearing to loose their means tested benefits if working on official market. Generally the man-woman distribution of responses on these questions is similar except from the one indicating the monetary advantage of working without contract - more frequent for women that for men. Younger and higher educated people more frequently give the tax evasion reason for working without formal contract than the others who stress more the need for the extra incomes. Generally the income constraint appears as a main reason for moonlighting.

The most frequent types of hidden activities are agriculture and gardening $(25 \%)$, construction and installation (14.2\%), car repairs and transport (12\%) and so-called neighborhood services $(13 \%)$. The majority of moonlighters is in the age between 25 and 44 $(52 \%)$ with the highest proportion for this age group. The participation in informal labor market is the fact of all education groups, but the most frequently concerns people with vocational and primary school level $(38 \%)$.

Almost all socio-demographic groups are concerned by the informal work. However the hidden economy activities are observed more frequently among low skilled workers and

\footnotetext{
${ }^{2}$ based on the Extended Labour Force Survey (ELFS) 1995. See Appendix A1 for details .
} 
jobs which do not need a high qualications. It seems that the large part of these activities is caused by the insufficient income and the dysfunctions of the official labor markets. Similarly hiring moonlighters looks like a research of low cost labor force, a kind of golden opportunity rather than a systematic choice for the tax evasion. As it was stressed by (Kalaska, Witkowski, 1996), the informal work "is a form of survival of both employers and a part of employees who have no chances on the official market"

In the post- transition period (2004) a similar study (GUS, 2005) showed relatively few changes in attitudes and opinions towards the informal activities.However, the shift from transition to post transition period weakened significantly the economic constraint and strengthened the tax burden effect as reasons of informal labour market participation. Indeed, in 2004 the lack of alternative than informal work and heavy tax burden were declared more often in 1995 than in 2004 as causes for taking up an informal work whereas insufficient incomes became less frequent motivation of informal activities in 2004 than in 1995. However their respective ranks among main motivations to participate in informal labor market remained the same. Morever, the observed differences in opinions since 1995 remained almost unchanged in 2004 whatever the sex, age, education group or the locality.

\section{Informal markets participation}

The analysis of informal labor market participation can be enlarged to the other underground activities - buying and hiring, following the explicit responses in the available survey. We define the "informal market participation" as a positive response to anyone out of three informal activities (working, buying, or hiring)..

We consider that a household participates in parallel activities if at least one of its members does it. In table 2 we present some general statistics about household's participation in the different types of underground activities. Almost $22 \%$ households are present on at least one of informal markets by one of its members, $15 \%$ are buying, $7.4 \%$ working and 6.8 hiring.

Almost $18 \%$ of households were present on the informal labour market. About 1,6\% of households combine both working and hiring, 2.5\% are buying and working and more than $5 \%$ are buying and hiring informally. This interdependence of certain informal activities will be discussed later in this section. 
Table 1

Opinions on the reasons for taking the unregistered employment in 1995 (as \% of the total)*.

\begin{tabular}{|l|c|c|c|c|c|}
\hline \multicolumn{1}{|c|}{ Specification } & Total & Men & Women & Urban & Rural \\
\hline Insufficient incomes & 63.0 & 61.6 & 64.2 & 63.1 & 62.7 \\
\hline $\begin{array}{l}\text { Inability to find an official } \\
\text { Job }\end{array}$ & 38.9 & 38.6 & 39.3 & 35.6 & 44.6 \\
\hline $\begin{array}{l}\text { Higher incomes without a } \\
\text { Contract }\end{array}$ & 16.2 & 18.1 & 14.5 & 17.2 & 14.6 \\
\hline Family or personal Situation & 8.7 & 6.7 & 10.4 & 8.9 & 8.2 \\
\hline Too high taxes & 24.2 & 26.8 & 21.8 & 26.0 & 21.1 \\
\hline $\begin{array}{l}\text { High social security } \\
\text { Contribution }\end{array}$ & 16.0 & 172 & 15.0. & 16.8 & 14.7 \\
\hline $\begin{array}{l}\text { Unwillingness to have a } \\
\text { Permanent job (flexibility) }\end{array}$ & 1.3 & 1.5 & 1.2 & 1.2 & 1.5 \\
\hline Fear to lose certain benefits & 10.3 & 10.7 & 10.0 & 10.9 & 9.3 \\
\hline Other & 0.1 & 0.1 & 0.1 & 0.1 & 0.1 \\
\hline
\end{tabular}

*several responses possible

Source: GUS Extended Labor Force Survey (1995), Kalaska, Witkowski, 1996.

Table 2

Frequencies of different forms of informal economy participation

\begin{tabular}{|c|c|c|c|}
\hline Nature of informal activities & $\mathrm{Nb}$ obs & Mean & Std Dev \\
\hline \multicolumn{4}{|l|}{--Households } \\
\hline Buying on informal markets & 10390 & 0.154 & 0.361 \\
\hline Working on informal markets & 10390 & 0.074 & 0.262 \\
\hline Hiring on informal markets & 10390 & 0.068 & 0.252 \\
\hline Participating (at least one out of three) & 10390 & 0.217 & 0.412 \\
\hline Working or hiring informal markets & 10390 & 0.179 & 0.383 \\
\hline Working and hiring on informal markets & 10390 & 0.016 & 0.125 \\
\hline Buying and working on informal markets & 10390 & 0.025 & 0.157 \\
\hline Buying and hiring on informal markets & 10390 & 0.053 & 0.224 \\
\hline
\end{tabular}

Source: Computed from GUS Extended Labor Force Survey (1995) 


\section{Socio-economic profiles and participation probabilities}

The definition of participation here is the declared by any person in the household any informal activity (buying, working, hiring) permanently or occasionally.. We consider, that the household's situation and needs determine the demand on informal market goods, services and activities. Another hypothesis going in the same sense is to consider that one informal activity is inducing another one, which can be done by the same or any other person member of the same household.

Overall household's participation probability increases with the number of children, it is higher in the countryside in families of farmers or double active working in the farm. Household's head unemployment is a strong factor increasing this probability while age is reducing it. University level of education increases considerably and significantly the participation probability, while other education categories have no significant impact (Appendix table B1).

The socio-economic profiles of participants change if various types of informal activities (working, buying, hiring) are taken into account (see Appendix table B1).

a. As expected, unemployment increases significantly the probability of not registered work, but reduces those of buying on informal market.

b. Male household's head has higher than female probability to work or hire without formal contract, but lower to buy on the informal market.

c. Living in a area with lower than country's average unemployment is related to the higher probability to hire and lower probability to work informally (which seems natural), whereas in the case of areas characterized by a higher than country's average unemployment, the probability to work informally is significant and higher than in the aeras with average unemployment.

d. There is no significant difference in the probability to participate in any informal activity with respect to the age, except from people above 60 for whom the informal work is significantly lower than for others. This is related very probably to the generally lower participation in the labour market.

e. The probability of participation do not vary for inhabitants of cities and towns except from hiring informally which rises significantly when the size of agglomeration is decreasing. However, living in the countryside rises very significantly the chances to participate in all informal activities.

f. Similarly farmers or double active (farmers and wage earners) have higher and significant probability to participate in all informal activities than wage earners. The self employed will only work informally with higher probability, but not to buy or hire.

g. The education level, has a small influence on participation behavior: high school education reduces the probability to work and university education increases the probability to buy on the informal markets.

$\mathrm{h}$. The family situation has a small impact on informal activities - the participation rises with the number of children with the most significant outcomes for informal work . Buying and hiring "on black" is more probable for families with 3 children than for smaller ones.

Generally it appears that it is in the rural environment, where the probability of all kind of informal activities is the highest.. Work without a formal contract is the most frequent in the case of unemployment or in the areas with relatively high unemployment. Informal hiring activities are more probable in cities but also among families with several children. The high 
probability of informal buying is related to high household head's education and the presence of a large family.

Thus, these relationships with respect to the informal activities appear to depend on the income or labour market situation, the rural or urban environment, but are age independent except from the "natural" labour supply decrease for the elderly.

\section{Are Buying, working and hiring on informal markets interdependent?}

Following Fortin et al, 2002, we question the existence of interdependence between various informal activities enlarging the analysis to the three types informal market activities: working, buying and hiring without formal contract in the context of Polish transition economy.

.We test this hypothesis using a recursive bivariate probit model of the probability to buy goods and services informally combined with other informal activities ( to work or to hire without formal contract) by including them as regressors. in the buying equation. We estimate three models combining (a) working and buying, (b) hiring and bying, (c) working or hiring and buying using seemingly unrelated regression allowing for residuals' correlation.

In order to take into account the possible endogeneity of dependent variables used as regressors we use the following estimation procedure. Firstly, we include the regional unemployment variables only in the equation of probability to work (or hire) supposing that there is few interdependence between them and the informal buying. Secondly, we instrument the dependent variable of the first equation (probability to work, to hire and to buy or hire) by simple probit method and put the instrumented value as a regressor into the buying equation.

The general specification of estimated models is the following system:

$\hat{\mathrm{y}}_{1}=\mathrm{f}_{1}\left(\mathrm{x}_{1}, \mathrm{x}_{2}, \ldots \mathrm{x}_{\mathrm{k}}\right)$

$\mathrm{y}_{2}=\hat{\mathrm{y}}_{1}+\mathrm{f}_{2}\left(\mathrm{x}_{1}, \mathrm{x}_{2}, \ldots \mathrm{x}_{\mathrm{k}-\mathrm{i}}\right)$

Where $\hat{\mathrm{y}}_{1}, \mathrm{y}_{2}$ dependent variables of informal activity probabilities, where ${ }^{\wedge}$ means instrumented value

$\mathrm{X}_{1}-\mathrm{X}_{\mathrm{k}}$ exogenous, socio-demographic and economic determinants,

$\mathrm{X}_{\mathrm{k}}-\mathrm{X}_{\mathrm{k}-\mathrm{i}}$ excluded exogenous variables

The summary results for three estimated models in terms of marginal effects are presented in the table 3. The full results are in Appendix B tables B2-B4..

(1) The marginal effect of working on informal market i.e the increase in probability to buy while working informally probability shifts from 0 to 1 is 0.45 . More generally, the shift in probability to participate in informal labour market (working or hiring) from 0 to 1 increases the probability to buy by 0.48 . These effects are particularly high, when compared with the average participation on informal consumption market of 0.15 .

(2) The closest relationship is observed between hiring and buying informally. The obtained marginal effect $(0.50)$ means that hiring informally increases the probability to buy informally by 50 percent . 
The estimated high marginal effects confirm the social network or neigburhood effects related with an easier access to different informal activities for those which are already present on at least one of informal markets. Moreover the results show a strong interdependence among various informal activities suggesting that participating in any of them can be a significant determinant explaining households' behavior.

We develop this conclusion in the next section considering the influence of the informal market participation on the households consumption behavior on the regular markets.

Table 3

Probability of buying working and hiring on informal markets Recursive bivariate probit model marginal effects*

\begin{tabular}{|c|c|c|c|}
\hline variable & $d y / d x$ & $\begin{array}{l}\text { dy/dx } \\
\text { Hire+bu }\end{array}$ & $\mathrm{dy} / \mathrm{dx}$ \\
\hline & Work+buy & $y$ & Hire or work+buy \\
\hline $\begin{array}{l}\text { Working on informal markets } \\
\text { (instrumented) }\end{array}$ & $0,451^{*}$ & $0,499 *$ & $0,484^{*}$ \\
\hline $\begin{array}{l}\text { Household's head } \\
\text { Unemployed }\end{array}$ & $-0,106$ & $-0,044^{*}$ & $-0,095^{\star}$ \\
\hline Inactive & $-0,075^{\star}$ & $-0,019$ & $-0,026^{*}$ \\
\hline $\begin{array}{l}\text { Household's head age less } \\
\text { than } 30\end{array}$ & $0,030^{*}$ & 0,018 & $0,029 *$ \\
\hline Household's head age $30-39$ & $0,033^{*}$ & 0,013 & $0,032^{*}$ \\
\hline Household's head age 40 - 60 & $0,091 *$ & 0,022 & $0,070^{*}$ \\
\hline University level education & $0,068 *$ & $0,056^{*}$ & $0,096^{*}$ \\
\hline High school level education & 0,030 & 0,015 & $0,053^{*}$ \\
\hline Primary school level education & 0,019 & 0,010 & 0,026 \\
\hline Farmers & $0,179^{*}$ & $-0,010$ & 0,022 \\
\hline $\begin{array}{l}\text { Double active (farmers+wage } \\
\text { earners) }\end{array}$ & $0,076^{*}$ & $-0,009$ & 0,013 \\
\hline Pensioneers & $0,057^{*}$ & $0,022^{*}$ & $0,029 *$ \\
\hline Self employed & $-0,009$ & & $-0,031$ \\
\hline One child & $-0,003$ & 0,004 & $-0,013$ \\
\hline Two children & $-0,014$ & $-0,006$ & $-0,030^{\star}$ \\
\hline $\begin{array}{l}\text { Three children or more } \\
\quad \quad \text { Significant at } 90 \% \text { level } \\
\quad \text { *See appendix B Tables B }\end{array}$ & $-0,029 \star$ & 0,003 & $-0,041^{*}$ \\
\hline
\end{tabular}

Source: Computed from GUS Extended Labor Force Survey (1995) 


\section{Participation to Informal Market s and Household Expenditures on Regular Markets}

We conclude from section 2 that the household's participation to the informal labour market may create a positive network effect on hiring labour services or purchasing goods on the black markets, both expenditures which may influence regular consumption because of substitution between regular and informal expenditures. Thus, both modes of participating to informal institutions may change the expenditures on regular markets. Indeed, if informal activities influence regular consumption, the estimation of regular demand as they are recorded in the HouseholdBudgets surveys may be biased whenever these informal activities are not taken into account. Moreover, considering them as potential explanatory variables may reduce part of the endogeneity biases which appear in cross-section estimations, and which are caused by the existence of permanent latent (unobserved) variables (see Gardes et al., 2005, for the biases of income elasticities computed on cross-sections). We try to deepen this question by proposing an approach combining the microeconomic consumption behavior analysis based on the typical household budget data with the information on the participation in informal markets contained in the Labour Force survey: integrating an index of unofficial activities in the equation for regular consumption may greatly improve cross-section estimates of all variables which are correlated, in the cross-section dimension, to these unofficial activities. The result would be cross-section estimates closer to time-series, which would solve the puzzle discussed in Gardes et al (2005).

In order to test for this dependency, we have imputed the probability to participate to informal markets for each household in the Family Expenditures surveys. For this analysis we use two statistically matched surveys: (i)the extended Labor Force Survey 1995 (ELFS 1995) containing specific information on informal economy participation (used in the previous section) and (ii) the Household Budget Survey (HBS 1995) with the associated four-years panel data (1993-1996) (see Appendix 2 for more details). First, demand systems are estimated on both time series (panel) and cross section data including the information on the participation on informal markets. Second, the income elasticities are compared between subpopulations with different participation probabilities. This comparison can indicate to what extent the use of informal markets is an economic constraint rather than a "golden opportunity" allowing simply to buy goods and services at lower price level.

\subsection{Specification, econometric methodology and data base construction}

The first step consists in setting up an appropriate data base. We use a regression based matching procedure to impute the informal market participation probabilities from ELFS 1995 into the 1994-96 Panel of Household Budget Surveys and the 1995 Household Budget Survey (HBS). The estimated model of participation in informal economy based on the 1995 ELFS Survey (see section 1 and table B1 in the Appendix B), is applied to predict the participation probabilities of each household in the panel and the survey (HBS) using similar households' characteristics. These predicted probabilities are added as explanatory variables in the demand systems analysis. Our hypothesis is that the households participating and non-participating in informal markets may behave differently, with respect to their socioeconomic characteristics, when facing a change in income, relative prices or other determinants of their consumption. We test this hypothesis estimating an Almost Ideal Demand System and a Quadratic Almost Ideal Demand System (QAIDS) on panel and crosssection expenditure data with the imputed information on informal market participation. The 
estimation of the Quadratic Almost Ideal Demand System QAIDS has been made using the convergence algorithm proposed by Banks et al. (1997):

For the linear Almost Ideal specification we have

$\mathrm{w}_{\mathrm{iht}}=\alpha_{\mathrm{i}}+\pi_{\mathrm{i}}$ part $+\Sigma_{\mathrm{j}} \gamma_{\mathrm{ij}} \ln \mathrm{p}_{\mathrm{jt}}+\beta_{\mathrm{i}} \ln \left[\mathrm{m}_{\mathrm{ht}} / \mathrm{a}\left(\mathrm{p}_{\mathrm{t}}\right)\right]+\mathrm{Z}_{\mathrm{ht}} \delta_{\mathrm{i}}+\mathrm{u}_{\mathrm{iht}}$

For the Quadratic specification

$$
\mathrm{w}_{\mathrm{iht}}=\alpha_{\mathrm{i}}+\pi_{\mathrm{i}} \text { part }+\Sigma_{\mathrm{j}} \gamma_{\mathrm{ij}} \ln \mathrm{p}_{\mathrm{jt}}+\beta_{\mathrm{i}} \ln \left[\mathrm{m}_{\mathrm{ht}} / \mathrm{a}\left(\mathrm{p}_{\mathrm{t}}\right)\right]+\left\{\left[\lambda_{\mathrm{i}} / \mathrm{b}\left(\mathrm{p}_{\mathrm{t}}\right)\right] \ln [\mathrm{m} / \mathrm{a}(\mathrm{p})]\right\}^{2}+\mathrm{Z}_{\mathrm{ht} .} \delta_{\mathrm{i}}+\mathrm{u}_{\mathrm{iht}},
$$

with: $\ln \mathrm{a}\left(\mathrm{p}_{\mathrm{t}}\right)=\alpha_{0}+\Sigma_{\mathrm{j}} \alpha_{\mathrm{i}} \ln \mathrm{p}_{\mathrm{it}}+0.5 \Sigma_{\mathrm{i}} \Sigma_{\mathrm{j}} \gamma_{\mathrm{ij}} \ln \mathrm{p}_{\mathrm{it}} \cdot \ln \mathrm{p}_{\mathrm{jt}} \quad$ and $\quad \mathrm{b}\left(\mathrm{p}_{\mathrm{t}}\right)=\Pi_{\mathrm{i}} \mathrm{p}_{\mathrm{it}}^{\beta \mathrm{i}}$

where $\mathrm{w}_{\mathrm{iht}}$ is the budget share for good $\mathrm{i}$, individual $\mathrm{h}$ and period $\mathrm{t}, \mathrm{p}_{\mathrm{it}}$ the price of good $\mathrm{i}, \mathrm{m}_{\mathrm{ht}}$ h's total income in period $t$, part the imputed probability of all members of the household to participate to informal consumption or activity and $Z_{\mathrm{ht}}$ all other socio-economic variables. Because of the possible endogeneity due to measurement errors of the income variable, it is instrumented by the total expenditure, the household head's age and its social category.

As the estimated parameters $\alpha_{\mathrm{i}}, \beta_{\mathrm{i}}, \gamma_{\mathrm{ij}}$ enter non-linearly into the equation, a first step consists to estimate equation $(2.1 \mathrm{~b})$ using a Stone price index $\mathrm{a}\left(\mathrm{p}_{\mathrm{t}}\right)=\prod_{i} p_{i \mathrm{i}} \overline{\bar{w}}_{\mathrm{i}}$ with $\bar{w}_{i}$ the average budget share of good $i$ over individuals and period (that is, imposing $\alpha_{0}=\gamma_{i j}=0$ and $\alpha_{\mathrm{i}}=\bar{w}_{i}$ in the true price index a $\left(\mathrm{p}_{\mathrm{t}}\right)$ ). Price elasticities can be corrected to take into account the difference between the exact price index $a\left(p_{t}\right)$ and the Stone index, as described by Pashardes (1990). In the second step, the $\beta_{\mathrm{i}}$ estimated are used to compute $\mathrm{b}\left(\mathrm{p}_{\mathrm{t}}\right)$. At each step, $\mathrm{b}\left(\mathrm{p}_{\mathrm{t}}\right)$ is updated and the system is linear in parameters. This procedure ensures that the quadratic specification which is estimated corresponds to the integrable QAIDS system.

Blundell and Robin (1999) proved the consistency and asymptotic efficiency of this iterative procedure compared to the maximum likelihood estimate. The estimation is made under the sole additivity hypothesis, as homogeneity is not accepted by the data except for clothing (note that the results are similar when homogeneity is constrained). The "between" and "within" parameters are estimated by pooling the three surveys with quarter and period dummies to take into account all institutional changes. The convergence process is rather low, $\mathrm{b}(\mathrm{p})$ converging at the $75^{\text {th }}$ iteration.

\subsection{The Effect of Informal Markets Participation on the Consumption Behavior}

The Almost IdealDS model (2.1a) is estimated on the 1995 Polish Household Budget Survey for 10 aggregated consumption items considered as a demand system with budget constraint (Table 4). Then, a panel sample covering the period 1994-1996 is used for system estimation (Apendix B, table B5).The final system estimation is performed using the same panel sample applying the quadratic version of the model (QAIDS) (Appendix B, table B6), resulting in four conclusions:

(a) The estimated coefficients of the probability to participation to the informal economy are very close for separate, equation by equation, demand system and between transformed data estimates, except for the item Culture and Education - traditionally a poorly defined category. For six groups of commodities out of eleven, the estimated probability to participate 
in the black market has a significant effect on regular expenditures in all types of estimation . The effect is clearly positive for Food, Alcohol and Tobacco, Transport and Communication with values from 10 to $30 \%$ of the budget share at the average probability of 0.3 (Table 4). The coefficient is negative for all other groups, especially for three services: Health, Education and Cultural expenditures (note that, under the additivity restriction, the coefficients for all groups sum up to 0 ). Such a negative effect of participation to the informal economy corresponds to a substitution between informal and regular expenditures: expenditures for goods or services of informal markets substitute for official expenditures. This substitution may be important for the three services which have the larger negative coefficients. A positive effect can be due to the influence of latent variables both on participation to informal markets and on the regular expenditures. Suppose for instance that the household is relatively poor in its reference population. This relative position tends to increase its food expenditures, compared to the normal effect of its current income (see Gardes, 2007, for the theory and an empirical analysis of this relative income effect). On the other hand, relative poverty increases the tendency to participate to the informal markets, so that a positive relationship appears between these two variables ${ }^{3}$. Therefore, income effects computed independently of its relative income position, would under-estimate its food consumption and artificially create a positive effect of this probability to participate. Conversely, luxury goods such as culture or health expenditures may be over-estimated. In a sense, the inclusion of this probability among the determinants of households expenditure control for relative income effects. It would be important to take into account both variable, relative income and black market participation, but this require to model explicitly the relative income effects, a difficult task.

\footnotetext{
3 The income from the informal labor market can also increase the consumption in excess of the part explained by official income declared by the household, whenever the household does not include in its declaration its unofficial income, but the specification on the instrumented total expenditure theoretically exclude such an under-estimation.
} 
Table 4

AIDS cross-section estimates of the change in budget shares according to the probability of participation in informal economy

\begin{tabular}{|c|c|c|c|}
\hline Expenditure groups & $\begin{array}{l}\text { Income } \\
\text { elasticity }\end{array}$ & $\begin{array}{l}\text { participation } \\
\text { probability }\end{array}$ & $\begin{array}{c}\text { average } \\
\text { budget share }\end{array}$ \\
\hline Food & 0.64723 & $\begin{array}{c}0.181289 \\
(5.028)\end{array}$ & 0.448 \\
\hline Alcohol and tobacco & 0.65111 & $\begin{array}{c}0.011839 \\
(1.015)\end{array}$ & 0.034 \\
\hline Clothing & 1.49340 & $\begin{array}{c}-0.045741 \\
(-2.177)\end{array}$ & 0.064 \\
\hline Dwelling (charges) & 0.87026 & $\begin{array}{c}-0.008299 \\
(-0.241)\end{array}$ & 0.184 \\
\hline Dwelling (equipment) & 2.19828 & $\begin{array}{c}0.018621 \\
(1.008)\end{array}$ & 0.032 \\
\hline Health & 1.08289 & $\begin{array}{c}-0.087720 \\
(-5.857)\end{array}$ & 0.042 \\
\hline Hygiene & 0.97142 & $\begin{array}{c}-0.004439 \\
(-0.642)\end{array}$ & 0.034 \\
\hline Education & 0.91242 & $\begin{array}{c}-0.066810 \\
(-7.172)\end{array}$ & 0.018 \\
\hline Culture & 1.73049 & $\begin{array}{c}-0.093797 \\
(-5.255)\end{array}$ & 0.047 \\
\hline Transport and communication. & 1.86568 & $\begin{array}{c}0.084119 \\
(0.606)\end{array}$ & 0.078 \\
\hline \multicolumn{4}{|c|}{$\begin{array}{l}\text { 1.Student (robust) statistics in parenthesis } \\
\text { 2.Income instrumented by total expenditure and socio-demographic variables. } \\
\text { 3.Income elasticities computed at the average level of budget share } \\
\text { source: Computed from GUS Household Budget Survey (1995) }\end{array}$} \\
\hline
\end{tabular}

(b) The comparison of the total expenditure elasticities (estimated by QAIDS) for two sub-populations: participating or non participating households, is given in the Table 5 . Half of the commodity groups have different time-series elasticities for the two subpopulations, but the order between the elasticities of the participating or not participating households are not the same for cross-section and time-series elasticities. Moreover, those commodities which are characterized by a large positive influence of participation (estimated in the constant) do not have larger income elasticity (in the within dimension) in the participating population. Perhaps the three types of participation have not similar effects as concerns the income elasticity. 
Table 5

Income Elasticity according to the Household's Participation to the Informal Economy

\begin{tabular}{|c|c|c|}
\hline & $\begin{array}{c}\text { Participating }>\text { Non- } \\
\text { Participating }\end{array}$ & $\begin{array}{c}\text { Participating }<\text { Non- } \\
\text { Participating }\end{array}$ \\
\hline Cross-section Elasticity & Dwellings (charges) & $\begin{array}{c}\text { Clothing, Dwelling } \\
\text { (equipment) }\end{array}$ \\
\hline Time-series Elasticity & $\begin{array}{c}\text { Clothing, Transport and } \\
\text { Communication }\end{array}$ & Food, Miscellaneous \\
\hline
\end{tabular}

Source: Computed from GUS Household Budget panel (1994-1995) (4809 observation per year

The explanation for the order between time-series elasticities -theoretically unbiased by the existence of permanent latent variables (which often bias the cross-section elasticities) cannot rely on relative income considerations: a continuous increase of households' income may not provoke a substitution between unofficial and official commodities, thus no endogenous bias may appear in the time-series income elasticities. The order of these timeseries elasticities may perhaps be partly explained by a different consumption behavior of rural and non-rural households. It can be also observed that participating households have higher income-elasticities for commodities which are already highly elastic: clothing, dwelling charges, transport and communication, as if supplementary income from informal activities or savings due to smaller prices on black markets are principally spent on luxury groups of commodities.

Note that it is highly plausible that the different types of participation to the informal sector differs between the rich and the poor: the former may buy unofficial goods and hire employees in the informal sector, while the latter may also buy goods (but different types of commodities) and sell their work informally. So, it may be important to differentiate these three types of participation to analyze consumption patterns and the constraints faced by the population.

(c) Another interesting feature of these statistics lies in the revealed choice conditions through the computation of shadow prices corresponding to rationing constraints or the existence of non-monetary resources. Such hidden determinants have been proved to explain the frequent biases in cross-section elasticities, compared to time-series. Those shadow prices are defined by changing consumption, through prices effects, in exactly the same amount as the change which is attributed to some latent variable. They measure, in price terms, the influence of this unobserved latent variable. For instance, optimizing under a rationing constraint (or conditionally to a definite amount of time spent in the consumption activity) lowers the optimal expenditure for the constrained commodity in exactly the same amount as that which is driven, through some calibrated direct price elasticity, by a price increase of a certain value for this commodity (see Appendix in Gardes et al., 2005; details and a more general model can be found in Gardes, 2008). Table 6 presents these shadow prices for participating and non participating households. Shadow prices are negatively related to the household's income when it does participate to the informal economy, while they are in the opposite positively related to income for the non-participating. This means that full prices (integrating these shadow prices) are greater for the poor among participating households, and 
the reverse for the rich not participating, which may create an incentive for the poor to gain from their participation to informal markets. The analysis thus shows an important economic determinant of the participation to the informal economy, and explains why this participation is more frequent among poor households.

Table 6

Shadow prices for participating and non-participating households

\begin{tabular}{|c|c|c|c|}
\hline $\begin{array}{c}\text { Commodity } \\
\text { group }\end{array}$ & Budget share & $\begin{array}{c}\text { Participating } \\
\text { Households }\end{array}$ & $\begin{array}{c}\text { Non- } \\
\text { Participating } \\
\text { Households }\end{array}$ \\
\hline Food & 0.448 & -2.45 & -0.47 \\
\hline $\begin{array}{c}\text { Alcohol- } \\
\text { Tobacco }\end{array}$ & 0.034 & -2.98 & $*$ \\
\hline Clothing & 0.064 & -0.64 & 0.99 \\
\hline $\begin{array}{c}\text { Dwelling } \\
\text { charges) }\end{array}$ & 0.184 & 0.63 & 0.09 \\
\hline $\begin{array}{c}\text { Dwelling } \\
\text { (equipment) }\end{array}$ & 0.032 & 0.27 & 0.88 \\
\hline $\begin{array}{c}\text { Transport and } \\
\text { Communication }\end{array}$ & 0.078 & -0.004 & -0.15 \\
\hline Health & 0.076 & 0.19 & 0.26 \\
\hline $\begin{array}{c}\text { Culture and } \\
\text { education }\end{array}$ & 0.065 & 0.12 & -1.17 \\
\hline Miscellaneous & 0.019 & 0.68 & 0.68 \\
\hline Weighted Mean & & -0.91 & 0.26 \\
\hline
\end{tabular}

Source: Computed from GUS Household Budget panel (1994-1995) (4809 observation per year) 


\section{Conclusion}

The use of the survey describing on the individual and household levels different types of informal activities (working, buying, hiring) makes possible to explore many new aspects of underground economy mechanisms. The characteristics of participants in informal markets differ when considering various types of underground activities but generally they are related with the constrained employment. Firstly, the rural population appears as the main actor of informal markets, probably because of the income constraints and also, because of the specificity of the labor market less developed in the countryside. Secondly the age and education level do not seem to influence the informal participation, which may show that this participation is more distributed all over the population than in other countries. Thirdly, the average regional unemployment rate is positively related to informal participation, even when the influence of the household regular activity has been already taken into account. It may indicate the existence of a network effect:a larger supply of informal goods and services increasing the household's exposure to informal activities, thus giving rise to a larger household's participation. Last, bachelor are more active in the informal economy, while large families seem to be less prone to participate to informal markets than families with only one or two children: this asymmetric relationship may be simply due to the existence of very large families in rural areas, although location have been taken into account in the estimation. It is possible that some supplementary cost to participate to the informal economy appears for large families compared to smaller.

The analysis of the characteristics of participants in informal markets thus confirms that working, buying and hiring on informal markets are mutually dependent. This is particularly the case of working and buying or hiring and bying .through the "network effect" where any contact with underground economy can facilitate other entries We test the importance of these dependencies using a set of bivariate estimations. The increase in probability to buy while working informally probability shifts from 0 to 1 is 0.45 . More generally, the shift in probability to participate in informal labour market (working or hiring) from 0 to 1 increases the probability to buy by 0.48 . These effects are particularly high, when compared with the average participation on informal consumption market of 0.15 . This confirm the interest in testing a structural model such as proposed by Fortin et al, 2002, in order to analyze the dependencies between various informal market participations and the potentially associated social stigma.

We analyze the possible existence of this network effect also indirectly comparing the cross-section and time series differences of income elasticities observed for participating and non participating households. This analysis, based on a matching method combining a labor force and a family budget surveys, turns out to show that the household's consumption behavior does depend, either negatively or positively according to the commodity group, on the informal market participation of the household. Moreover, the difference between the cross-section and the time-series estimates of the income effect is lowered by the presence of a participation probability among the explanatory variables, which is an important indication that this participation acts as a proxy for a lot of latent variables which cause the endogeneity biases on the cross-section estimates: it may be important to take into account an imputed participation rate in order to $\mathrm{b}$ e able to estimate income-elasticities on cross-section lowering the endogeneity bias. Third, shadow prices indicating the presence of constraints or nonmonetary resources (such as those proceeding from a hidden time constraint) seem to depend on the household's participation to the informal economy: this indicates that those participating households may face different economic costs which explain their participation to the informal markets. 
1-3. La présentation de l'article a été modifié en développant l'introduction, la revue de la littérature et en homogénéisant les sources des données utilisée dans la partie descriptive (Seule l'unité d'observation « ménage » a été retenue et celle de l'individu -éliminée).

Dans la partie introductive de la section 1, nous avons mis en perspective la situation de la Pologne par rapport à d'autres pays de transition et rappelé la particularité de la transition concernant le marché informel. Nous avons aussi actualisé et élargie la bibliographie.

Nous avons complété la présentation des données et précisé la méthode de constitution des échantillons de travail. Les tableaux des statistiques descriptives ont été ajoutés en annexe. Nous avons expliqué les variables utilisées dans les régressions.

Dans le modèle de participation nous avons sélectionnés parmi les variables disponibles celles qui étaient susceptibles d'être significatives et communes au LFS (enquête emploi) et HBS (enquête budgets des ménages). Les revenus de ménages ne sont pas renseignés dans le LFS. L'appariement statistique entre les deux enquêtes pour expliquer la probabilité de participation est une suggestions intéressante, mais c'est une autre façon de montrer de ce qu'il a été fait dans la seconde section.

4. Nous avons ajouté l'analyse des déterminants de la participation activité par activité dans le texte avec renvoi au tableau dans l'annexe (tableau A3).

Nous avons renoncé à l'analyse dynamique (entre le 1995 et 1998) en considérant la période séparant les deux dates comme un peu courte. Le choix de l'année 1995 plutôt que 1998 a été guidé par la meilleure qualité des réponses pour cette année constatée par les auteurs de l'enquête (L'office stattistique national GUS). Nous ne disposons pas de l'enquête 2004. Nous avons en revanche ajouté un commentaire sur l'évolution des opinions et les motivations de participation entre 1995 et 2004 en utilisant les sources publiées de l'enquête 2004.

Nous avons fait le choix d'analyse au niveau de ménage parce que c'est une unité d'observation sur laquelle les deux sources statistiques utilisées (enquête sur l'emploi et l'enquête de consommation) sont appariées. Notre hypothèse consiste à considérer la situation du ménage en fonction de la probabilité de participation au marché informel de n'importe quel membre du foyer.

5. Notre choix initial dans le papier a été d'analyser l'offre et la demande du travail au noir et son impact éventuel sur la demande de consommation (biens et services). Conformement à la suggestion nous l'avons élargi dans la version corrigée aux liens entre la consommation informelle et l'offre ou la demande du travail. Dans ce contexte, plus encore que dans le cas précédent le lien entre la consommation et la présence sur le marché du travail semble naturel. D'autres liens possibles (l'embauche et le travail, ou l'embauche et l'achat) sont intéressants en soi, mais sans suite dans la deuxième partie. Nous avons ajouté et commenté brièvement ces relations dans la partie descriptive (tab 2).

6.Nous avons refait les estimations conformément aux suggestions en utilisant le probit bivarié (système à équations simultanées) pour tenir compte des effets de l'endogenéité. Nous avons élargi l'analyse aux relations entre le travail, l'embauche, et la présence sur le marché du travail informel d'une part et l'achat sur le marché informel d'autre part. Cette estimation a bien montré le lien significatif entre le travail et achat au noir et d'une manière plus générale entre l'achat et participation au marché informel du travail (l'offre et la demande du travail informel) ainsi que l'effet significatif d'endogéneité.

6. Le lien entre les deux sections...

9. La probabilité de participation utilisée dans la $2^{\text {ème }}$ section est une prédiction de la participation dans l'enquête de consommation (HBS) à partir du modèle estimé avec l'enquête emploi (ELFS), conditionnellement aux caractéristiques de ménages. De ce fait cette variable ne devrait plus être endogène et le problème ne se pose pas. En revanche la variable revenu est effectivement instrumentée par la dépense totale, catégorie socio- professionnel et age du chef de ménage. Nous avons introduit un bref commentaire dans le texte. 
10 La description de la constitution de l'échantillon a été complétée dans l'Annexe A.

\section{Variabilité du panel}

12 methodologie du panel justifier

13 L'anglais a été revu

\section{Remarques secondaires}

14. Bibliografie a été revue et complétée.

15. C'est vrai qu'il s'agit dans la plupart des cas des contraintes nouvelles et c'est le sens de la deuxième section. En revanche il difficile l'agriculture était devenu une agriculture de subsistance beaucoup plus pendant la transition par rapport à la situation d'avant, où le niveau de vie moyen à la campagne a été supérieur au niveau de vie des ouvriers et des employés dans les villes. Les agriculteurs ont été les grands perdants de la transition.

16. En effet 1994-1996 est une période de transition, nous avons éliminé du texte les passages ambigus.

17. Nous avons changé le titre: The informal activities and consumption of Polish households during the transition.

18. Nous utilisons alternativement activités informelles et marchés informels sans faire la référence à l'ampleur macroéconomique de la question.

19.Les raisons de participation sont différentes selon la catégorie de ménages, et résultent à la fois des contraintes et des effets d'aubaine. La section 2 apporte les éléments de réponses en utilisant la notion de prix virtuels.

\section{Effet miltiplicateur après la transition?}

21. Il a l'analyse en terme des prix virtuels qui traduit à la fois les effets de contraintes et des ressources non monétaires (dans la section 2).

22. On utilise également d'autres variables de LFS, que celles du volet « travail informel). Nous avons renoncé à l'analyse dynamique (entre le 1995 et 1998) en considérant la période séparant les deux dates comme un peu courte. Le choix de l'année 1995 plutôt que 1998 a été guidé par la meilleure qualité des réponses pour cette année constatée par les auteurs de l'enquête (L'office statistique national GUS). Nous ne disposons pas de l'enquête 2004.

23. Nous avons regroupé les informations sur les sources utilisées dans l'annexe A (avec renvois à partir de la première et deuxième section) et nous avons détaillé la construction de la base de données spécifique utilisée dans la section 2 dans l'introduction à cette section.

24. Effectivement, par choix nous n'avons pas fait une analyse détaillée des activités informelles. Cela avait été fait dans les publications citées (GUS 1996 par exemple). Notre objectif principale a été seulement de distinguer entre les ménages avec et sans activités informelles et analyser les liens entre différentes formes de ces activités. La question de saisonnalité et du cumul avec du travail formel aurait été abordée si on avait voulu valoriser le travail informel et le comparer avec l'apport monétaire du travail officiel. En revanche les disparités régionales on été abordés par l'introduction parmi les facteurs explicatifs la participation à l'activité informelle le taux de chômage locale. Par ailleurs les régions géographiques ne sont pas vraiment traitées à cause des limites des statistiques officielles sinon par un regroupement souvent imprécis des unités administratives (voïvodie, powiat...).

25. Nous avons limité l'analyse au seul niveau «ménages ». Par souci de cohérence, nous avons éliminé quelques passages avec des références aux données individuelles. L'échantillon utilisé compte 10390 ménages. II a été constitué à partir des fichiers individuels hommes, femmes en utilisant l'identifiant « ménages ». Le nombre d'observations utilisées a été ensuite légèrement réduit à cause des valeurs manquantes ou incohérences.

26. La date de l'enquête a été corrigée.

27. Ces statistiques ont été intégrées dans le tableau dans le texte. 
28.

29. La probabilité de participation au marché informel a été imputée à partir de l'enquête ELFS 1995 à l'enquête HBS 1995. Le panel HBS contient les ménages de cette même enquête HBS 1995, qui sont présent également dans les enquêtes 1994 et 1996. Les statistiques descriptives ont été ajoutées dans l'annexe A.

30.

31

32 On a ajouté dans la conclusion... 
Nous avons amélioré la présentation des données utilisées, de la méthode économétrique et nous avons restructuré l'ensemble de l'article.

0. Nous avons élargie la discussion et revue de la littérature sur la question du marché informel et particulièrement dans le contexte de la transition.

Nous avons mieux exposé la question de la demande du travail au noir en la distinguant explicitement dans les statistiques descriptives et dans l'approche économétrique.

Nous n'avons pas traité la question de l'opprobre social associé au recours au marché noir faute d'information suffisante. Une longue tradition de coexistence des activités informelles et formelles fait que l'opprobre et sans doute faible surtout en ce qui concerne le travail au noir. Souvent imposé par l'employeur, le travail au noir n'est pas perçu comme un délit par les travailleurs. Nous discutons brièvement cette question dans la première partie de la section 1. On ne répond pas à la problèmatique...

1.Les informations sur les sources de données utilisées ont été regroupé dans l'annexe $A$ avec des statistiques descriptives.

Les statistiques présentées dans le papier se réfère au ménage comme unité d'observations. Par souci de cohérence les statistiques au niveau individuel ont été éliminées du papier. Les données sur les activités informelles proviennent de l'enquête sur les forces de travail (LFS) couvrant l'année 1995.

Les statistiques concernant différents types d'activités informelles ont été complétées et se trouvent dans le tableau 2.

1. Nous avons refait les estimations conformément aux suggestions en utilisant le probit bivarié (système à équations simultanées) pour tenir compte des effets de l'endogenéité. Nous avons élargi l'analyse aux relations entre le travail, l'embauche, et la présence sur le marché du travail informel d'une part et l'achat sur le marché informel d'autre part. Cette estimation a bien montré le lien significatif entre le travail et achat au noir et d'une manière plus générale entre l'achat et participation au marché informel du travail (l'offre et la demande du travail informel).

2. Nous avons précisé la spécification du modèle utlisé dana la section 2 


\section{References}

BANKS J., BLUNDELL R., LEWBEL A., [1997], “ Quadratic Engel Curves and Consumer Demand", Review of Economic Studies, 89, 4, 527-539.

BERGER K, [1996], "Gospodarstwo domowe w gospodarce rynkowej - wyniki badania Ankietowego", dans : Szara Gospodarka w Polsce, GUS-ZBSE, Warszawa

BERNABÈ S. , STAMPINI M, [2008] Labour Mobility during Transition: Evidence from Georgia” Discussion Paper 206/2008, Katholieke Universiteit Leuven.

BERNABÈ S. [2002] "Informal employment in countries in transition: a conceptual framework ". Discussion Paper. Centre for Analysis of Social Exclusion, London School of Economics and Political Science, London, UK.

BLUNDELL R., ROBIN M. [1999], “An Iterated Least Squares Estimator for Conditionally Linear Equations Models”, Journal of Applied Econometrics 14, 209-232.

CASE, [2006] Unregistered Employment in Poland, CASE Report , Poland

CHAREMZA W. [1990], "Parallel markets, excess demand and virtual prices: An empirical Approach “, European Economic Review 34, 331-339.

CHAREMZA W., QUANDT R.E. [1982], "Models and estimation for centrally planned markets in disequilibrium, Review of Economic Studies 49, 109-116.

COWELL F. A [1985]. "Tax evasion with labour income”. Journal of Public Economics, 26(1), p. 19-34.

COWELL, F. A. [1990] "Tax Sheltering and the cost of evasion" Oxford Economic Papers, 42, p.231-243.

DIAYE M.A., GARDES F., STARZEC C. [2008], "Garp violation, Economic Environment Distortions and Shadow Prices: Evidence from Household Expenditure Panel Data”, I.

forthcoming in Les Annales d'Economie et de Statistique

DUPAIGNE M., HÉNIN P.Y. [2001], “A Dynamic Macro Model of the Informal Economy”, Working paper Cepremap-CERGE, septembre.

FEIGE, EDGAR L. [1997]. "Underground Activity and Institutional Change:Productive, Protective and Predatory Behaviour in Transition Economies," dans Transforming PostCommunist Political Economies. National Academy Press, Washington, D.C.

FORTIN B. [2002], «Les Enjeux de l'Economie Souterraine », Présentation à la Société Royale du Canada, Université Laval, 1 novembre.

FORTIN, B., JOUBERT N., LACROIX G. 1[(2004], « Offre de travail au noir en présence de la fiscalité et des contrôles fiscaux «, Économie et Prévision, N 164-165, 145-164. 
FORTIN B, JOUBERT N., LACROIX G. [2002], « Fiscalité, effets de voisinage et offre de travail au noir» Working Paper 02-14, GATE, Université lumière Lyon 2.

FORTIN, B., G. LACROIX G. [1994], "The Marginal Cost of Public Funds in the Presence of an Irregular Sector : An Empirical Investigation", The Journal of Public Economics, 55,407431.

FORTIN, B. G. LACROIX , C. MONTMARQUETTE [2000], “Are Underground Workers More Likely to be Underground Consumers ?",The Economic Journal, Vol. 110, 466, 838860.

FORTIN, B. G. LACROIX G., VILLEVAL M.-C. [2007], "Tax Evasion and Social Interactions", Journal of Public Economics, 91, 2089-2112.

GARDES, F. [2007], "Looking For Another Relative Engel's Law", Working Paper. CES, April.

GARDES, F. [2008], “Riemanian Consumers ”, Working Paper. CES, May.

GARDES F., G. DUNCAN G., GAUBERT P., GURGAND M, STARZEC C. [2005]," Panel and Pseudo-Panel Estimation of Cross-Sectional and Time Series Elasticities of Food Consumption, the Case of US and Polish Data", Journal of Business and Economic Statistics, April 2005, Vol. 23, $\mathrm{N}^{\circ} 2$, p.242-253.

GARDES F., GAUBERT P., LANGLOIS S. [2000], "A New Measure of Poverty in Canada, 1969-1996”, Canadian Journal of Sociology and Anthropology , p. 1-31.

GUS, 1996, Szara Gospodarka w Polsce, GUS-ZBSE, Warszawa.

GUS, [2005], "Praca nierejestrowana w Polsce w 2004", Informacje i opracowania statystyczne Warszawa

KALASKA M., WITKOWSKI J. 1996, "Praca nierejestrowana w Polsce w 1995 rokuwyniki badania ankietowego", in : Szara Gospodarka w Polsce, GUS-ZBSE, Warszawa.

KAUFMANN D., KALIBERDA A. [1996]. “An 'Unofficial' Analysis of Economies in Transition: An Empirical Framework and Lessons for Policy." Development Discussion Paper,558, Harvard Institute for International Development: Cambridge, MA..

KORDOS J., KUBICZEK A, [1991], Methodological Problems in the Household Budget Surveys in Poland, GUS, Warsaw.

KOSTRUBIEC S. (ed), [1999], "Praca nierejestrowana w Polsce w 1998 roku;" GUS, Warszawa.

KURKCHIYAN, M.. [2000]. "The Transformation of the Second Economy into the Informal Economy," in Economic Crime in Russia. Alena V. Ledeneva and Marina Kurkchiyan eds. The Hague: Kluwer Law International

LACROIX, G., FORTIN B. [1992], "Utility-Based Estimation of Labor Supply Function 
in the Regular and Irregular Sectors”, The Economic Journal, 102, p. 1407-1422.

LEMIEUX, T., FORTIN B., FRÉCHETTE P.[1994], "The Effect of Taxes on Labor Supply in the Underground Economy", American Economic Review (84:1), p. 231-254.

MANSKI, C.F. [1993] "Identification of Endogenous Social Effects: The Reflection Problem," Review of Economic Studies, 1993a, 60, p. 531-542.

MANSKI, C.F. [2000]. "Economic Analysis of Social Interactions". Journal of Economic Perspectives 14(3), p.115-36.

MUNDLAK Y., [1978], "On the Pooling of Time Series and Cross Section Data", Econometrica 46, p. 483-509.

OECD [1997]."Framework for the Measurement of Unrecorded Economic Activities in Transition Economies." OECD: Paris OCDE/GD(97)177.

RAJEWSKI Z., ZIENKOWSKI L. [1996], "Szara gospodarka w systemie rachunkow narodowych", in : Szara Gospodarka w Polsce, GUS-ZBSE, Warszawa.

ZIENKOWSKI L. [1996] "Szacunek rozmiarow szarej gospodarki (synteza)", in : Szara Gospodarka w Polsce, GUS-ZBSE, Warszawa.

SCHNEIDER, F. [2007]: „Shadow Economies and Corruption all over the World: New Estimates for 145 Countries", Economics: The Open Access, Open Assessment E-Journal $N^{\circ} 2007-9$

STARZEC K., [1983], »L'économie polonaise vue à travers des circuits parallèles », Consommation, $\mathrm{N}^{\circ} 4$. 


\section{APPENDix A}

\section{Data sources}

\section{Unregistered economy survey ( Extended Labor Force Survey (ELFS), GUS 1995)}

The new phenomenon of informal employment as collateral consequence of appearing and increasing dramatically unemployment was the main motivation for a special study conducted by Polish Statistical Office (GUS) in 1995. One of the most important points of the interest was the probable overestimation of the formal unemployment scale by evaluating the number of formally unemployed working in the unregistered activities induced both by tax evasion in the new private sector and by possible combining of the unemployment benefit with informal work. A large scale survey was launched with questions on hidden markets activities as a part of regular Labor Force Survey (LFS). LFS is household based survey. The ordinary dwellings are selected in two step sampling method. The working status questions apply to households members aged 15 and more. A specific questionnaire was elaborated and presented to the half of households selected for the quarterly LFS. A principle was adopted to use for this study the sub sample of persons finishing their cooperation with GUS after having participated in three consecutive waves of LFS. In total over 11000 households took part in the study and the information about 25.6 thousand persons living in was collected. Only 546 persons refused to take part in the survey. The survey was performed in August 1995.

Main features of the hidden economy survey:

-Nation wide character: thanks to the modular character of the survey matched with LFS study all information is representative for the whole population and applying appropriate weights national scale estimates can be obtained.

-Common core variables with LFS study: in addition to specifically "hidden market" questions all socio-economic information on household is available from LFS study.

-Demand-supply side of the phenomenon: information was collected on both the demand for informal work and supply of the labor in the hidden economy asking corresponding questions to workers and persons running a private business.

-Informal work characteristics: the distinction was made between persons working only in the hidden sector and combining formal and hidden one.

-Different types of informal jobs were distinguished

Detailed characteristics of types of activities in informal sector are given: hidden market consumption characteristics, reasons of taking informal job incomes and expenditures on hidden markets.

\begin{tabular}{|l|r|l|l|}
\hline Variable & Obs & Mean & Std. Dev. \\
\hline Household's head Unemployed & 10390 & .0383061 & .1919434 \\
\hline Household's head Working & 10390 & .360924 & .4802916 \\
\hline Household's head Man & 10390 & .6842156 & .4648499 \\
\hline Household's head Woman & 10390 & .3157844 & .4648499 \\
\hline $\begin{array}{l}\text { Department unemployment below } \\
\text { the national average. }\end{array}$ & 10390 & .4475457 & .4972649 \\
\hline $\begin{array}{l}\text { Department with average } \\
\text { unemployment }\end{array}$ & 10390 & .2980751 & .4574347 \\
\hline
\end{tabular}




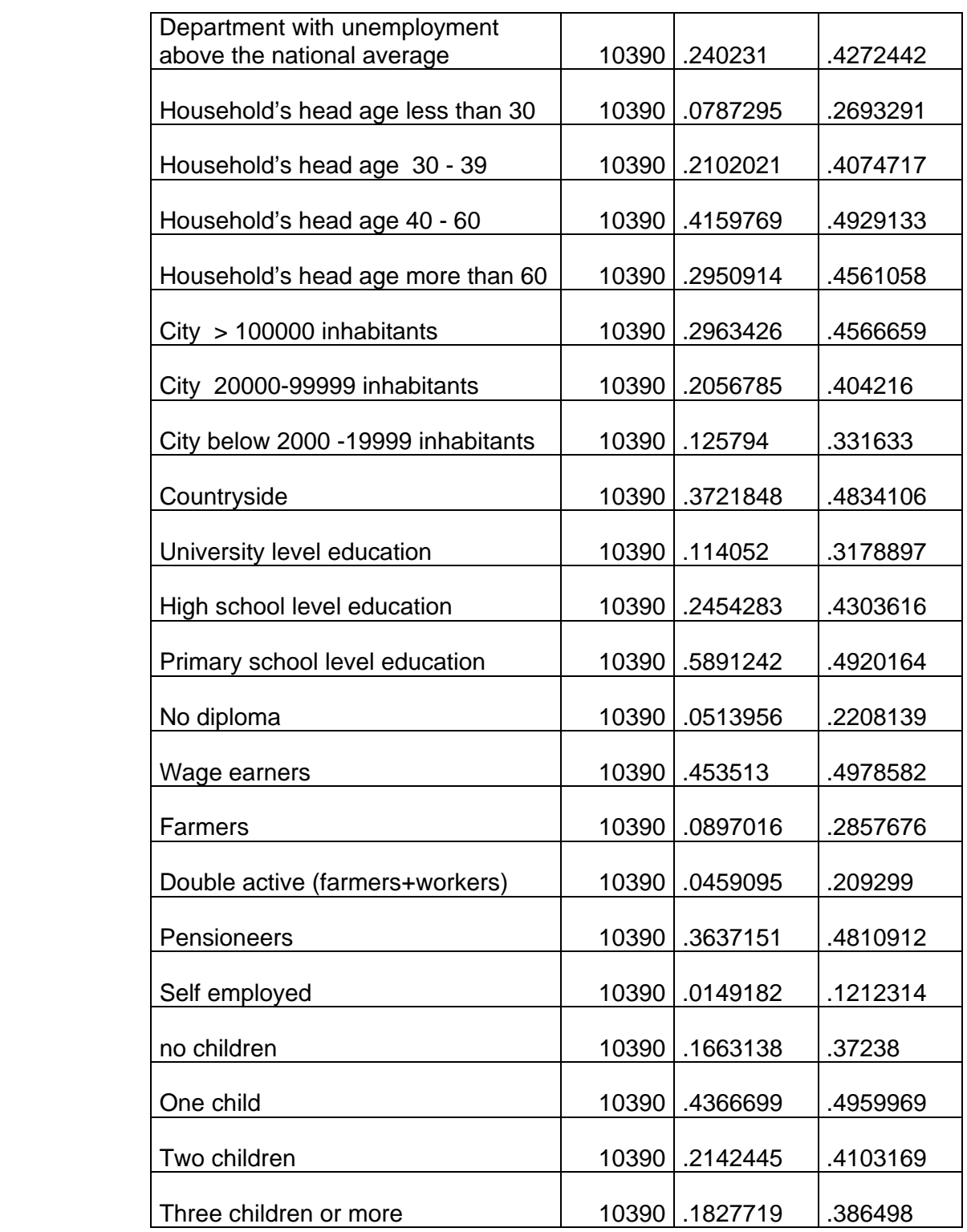

Source: Extended Labor Force Survey (ELFS), GUS 1995)

\section{The Polish Household Budget Surveys (HBS) and Panels}

Household budget surveys have been conducted in Poland for many years. In the analyzed period, the annual total sample size was about 30000 thousand households, which represent approximately $0.3 \%$ of all households in Poland. The data were collected by a rotation method on a quarterly basis. The master sample consists of households and persons living in randomly selected dwellings. To generate it, a two stage, and in the second stage, two phase sampling procedure was used. The full description of the master sample generating procedure is given by Kordos et al. (1991). 
Master samples for each year contain data from four different sub-samples. Two subsamples started to be surveyed in $1986(1992,1996)$ and ended the four years survey period in 1990 (1996, 2000). They were replaced by new sub-samples in 1990 (1993, 2000). Another two sub-samples of the same size were started in $1987(1993,1997)$ and followed through $1990(1996,2000)$.

Over this four year periods on every annual sub-sample it is possible to identify households participating in the surveys during all four years. The checked and tested number of households is 3707 and 3052 for the earlier and later panels respectively. The available information is as detailed as for the cross-sectional surveys: all typical socio-economic characteristics of households and individuals are present, as well as details on income and expenditures.

The period 1987-1990 covered by the Polish panel is unusual even in Polish economic history. It represents the shift from a centrally planned, rationed economy (1987) to a relatively unconstrained fully liberal market economy (1990). Thus, the transitory years 1988 and 1989 produced a period of a very high inflation and a mixture of free-market, shadow and administrated economy. The 1993-1996 panel reflects the main transition period, the 1997-2000 one corresponds to the post transition high economic growth period with relatively low inflation, decreasing unemployment and generally improved socio-economic situation in the context of almost totally liberalized economy.

In our estimations we use both a three year 1994-1996 periodof the $1993-1996^{4}$ panel and 1995 cross-section data containing the same variables. The number of households (our observation unit) in panel is 4809 and in 1995 survey about 32000. For descriptive statistics see table A2

Table A2

Averages and of variables used in consumption models (Household Budget Survey (HBS) 1995)

\begin{tabular}{|c|c|c|c|}
\hline Variable & $\begin{array}{c}\text { number of } \\
\text { observation }\end{array}$ & Mean & Std. Dev. \\
\hline total income & 31857 & 1226,055 & 1163,859 \\
\hline total expenditure| & 31857 & 1120,649 & 909,641 \\
\hline average head's age & 31857 & 48,664 & 14,563 \\
\hline heads age less than 30 & 31857 & 0,101 & 0,301 \\
\hline head's age 30-40 & 31857 & 0,226 & 0,418 \\
\hline head's age 40-60 & 31857 & 0,436 & 0,496 \\
\hline head's age more than 60 & 31857 & 0,237 & 0,425 \\
\hline number of adults in households & 31857 & 2,423 & 1,409 \\
\hline number of children & 31857 & 0,769 & 1,146 \\
\hline city 250000 and more & 31857 & 0,350 & 0,477 \\
\hline city 50000 -250 000 & 31857 & 0,186 & 0,389 \\
\hline city less than 50000 & 31857 & 0,126 & 0,331 \\
\hline countryside (less than 2000) & 31857 & 0,338 & 0,473 \\
\hline workers & 31857 & 0,440 & 0,496 \\
\hline farmers| & 31857 & 0,065 & 0,247 \\
\hline Double active (farmers+workers) & 31857 & 0,053 & 0,223 \\
\hline Pensioneers & 31857 & 0,346 & 0,476 \\
\hline Self employed & 31857 & 0,137 & 0,296 \\
\hline number of children=2 & 31857 & 0,141 & 0,348 \\
\hline
\end{tabular}

\footnotetext{
${ }^{4}$ The yaet 1993 was not used because of the absence of some variables in the version we had.
} 


\begin{tabular}{|c|c|c|c|}
\hline number of children=3 & 31857 & 0,166 & 0,372 \\
\hline number of children=4 & 31857 & 0,059 & 0,235 \\
\hline number of children more than 4 & 31857 & 0,026 & 0,160 \\
\hline university and post secondary diploma & 31857 & 0,119 & 0,324 \\
\hline secondary school & 31857 & 0,282 & 0,450 \\
\hline primary school & 31857 & 0,576 & 0,494 \\
\hline no diploma & 31857 & 0,023 & 0,151 \\
\hline food budget share & 31857 & 0,448 & 0,151 \\
\hline alcohol and tobacco budget share & 31857 & 0,034 & 0,044 \\
\hline clothing budget share & 31857 & 0,064 & 0,077 \\
\hline dwellingt budget share & 31857 & 0,184 & 0,131 \\
\hline furniture budget share & 31857 & 0,032 & 0,067 \\
\hline health budget share & 31857 & 0,042 & 0,056 \\
\hline hygiene budget share & 31857 & 0,034 & 0,025 \\
\hline culture budget share & 31857 & 0,018 & 0,036 \\
\hline education budget share & 31857 & 0,047 & 0,068 \\
\hline transport and communication bugdet share & 31857 & 0,078 & 0,090 \\
\hline miscelenoeus & 31857 & 0,019 & 0,046 \\
\hline
\end{tabular}

Source: GUS, Household Budget Survey 1995 
Table B1

Probability of participating (buying, working or hiring) on informal markets: Logistic function estimates (data on households)

\section{Summary table}

Variable

INTERCEPT

Household's head inactive

Household's head Unemployed

Household's head Working

Household's head Man

Household's head Woman

Local unemployment ,below the national

average

Local unemployment with average

unemployment

Local unemployment, above the national

average

Household's head age less than 30

Household's head age $30-39$

Household's head age $40-60$

Household's head age more than 60

City $>100000$ inhabitants

City 20000-99999 inhabitants

City below 2000 -19999 inhabitants

Countryside

University level education

High school level education

Primary school level education

No diploma

Wage earners

Farmers

Double active (farmers+wage earners)

Pensioneers

Self employed

no children

One child

Two children

Three children and more
Participating(1

)

\begin{tabular}{|c|c|c|c|}
\hline$-0,429$ & 0,227 & 0,211 & 0,369 \\
\hline$-0,491$ & 0,106 (ns) & 0,097 & 0,186 \\
\hline $\begin{array}{l}0,372 \\
\text { reference }\end{array}$ & $\begin{array}{l}0,127 \\
\text { reference }\end{array}$ & $\begin{array}{c}0,193 \\
\text { reference }\end{array}$ & $\begin{array}{l}0,715 \\
\text { reference }\end{array}$ \\
\hline $\begin{array}{l}-0,319 \\
\text { reference }\end{array}$ & $\begin{array}{l}0,072 \\
\text { reference }\end{array}$ & $\begin{array}{l}0,069(\mathrm{~ns}) \\
\text { reference }\end{array}$ & $\begin{array}{l}0,121 \text { (ns) } \\
\text { reference }\end{array}$ \\
\hline$-0,145$ & 0,073 & 0,065 (ns) & 0,105 \\
\hline reference & reference & reference & reference \\
\hline $0,038(\mathrm{~ns})$ & 0,079 & 0,075 (ns) & 0,117 \\
\hline reference & reference & reference & reference \\
\hline$-0,050$ (ns) & 0,114 & 0,119 (ns) & 0,171 (ns) \\
\hline$-0,113$ (ns) & 0,113 & 0,117 (ns) & 0,168 (ns) \\
\hline $\begin{array}{l}-0,117(\mathrm{~ns}) \\
\text { reference }\end{array}$ & $\begin{array}{l}0,147 \\
\text { reference }\end{array}$ & $\begin{array}{c}0,137 \\
\text { reference }\end{array}$ & $\begin{array}{l}0,203 \\
\text { reference }\end{array}$ \\
\hline$-0,043(n s)$ & 0,098 (ns) & 0,089 (ns) & 0,257 \\
\hline 0,057 (ns) & 0,109 (ns) & 0,106 (ns) & 0,256 \\
\hline 0,422 & 0,089 & 0,081 & 0,217 \\
\hline$-0,046$ (ns) & 0,193 & 0,160 & 0,292 (ns) \\
\hline$-0,300$ & 0,175 & 0,148 (ns) & 0,234 \\
\hline$-0,124$ (ns) & 0,160 & 0,135 (ns) & 0,204 \\
\hline reference & reference & reference & reference \\
\hline reference & reference & reference & reference \\
\hline 0,842 & 0,104 & 0,090 & 0,112 \\
\hline 0,328 & 0,135 (ns) & 0,115 & 0,130 \\
\hline 0,209 & 0,107 (ns) & 0,101 & 0,159 \\
\hline $\begin{array}{l}0,560 \\
\text { reference }\end{array}$ & $\begin{array}{l}0,219 \\
\text { reference }\end{array}$ & $\begin{array}{l}0,298(\mathrm{~ns}) \\
\text { reference }\end{array}$ & $\begin{array}{c}\mathrm{n} \\
\text { reference }\end{array}$ \\
\hline$-0,762$ & 0,136 & 0,112 (ns) & 0,207 (ns) \\
\hline$-0,282$ & 0,087 & 0,083 (ns) & 0,119 (ns) \\
\hline$-0,152$ & 0,089 & 0,087 (ns) & 0,120 \\
\hline
\end{tabular}

1 Log likelihood $=-5719.4899$, LR chi2(21) $=670.58$, Prob $>$ chi $2=0.0000$, Number of obs $=10390$,

2 Log likelihood $=-3623.511$, LR chi2(21) $=497.20$, Prob $>$ chi $2=0.0000,$, Number of obs $=10390$

3 Log likelihood $=-4270.665$, LR chi2(21) $=422.64$, Prob $>$ chi $2=0.0000$, , Number of obs $=10390$

4 Log likelihood $=-1841.554$, LR chi2(20) $=1675.70$, Prob $>$ chi2 $=0.0000$, Number of obs $=10235$

(ns) not significant

Source: Computed from GUS Extended Labor Force Survey (1995), 1039 obs 
Table B2

Probability of buying and working on informal markets Recursive bivariate probit model

$\begin{array}{ll} & \text { Robust } \\ \text { Coef. } & \text { St. Error } z \quad P>|z|\end{array}$

Working equation |

Household's head Unemployed

Inactive

Local unemployment below the national average.

Local unemployment above the national average

Household's head age less than 30

Household's head age 30 - 39

Household's head age $40-60$

City 20000-99999 inhabitants

City below 20000 inhabitants

Countryside

University level education

High school level education

Primary school level education

Farmers

Double active (farmers+wage earners)

Pensioneers

Self employed

One child

Two children

Three children or more

constant

$\begin{array}{rrrr}0,538 & 0,074 & 7,290 & 0,000 \\ -0,037 & 0,057 & -0,650 & 0,519 \\ -0,145 & 0,039 & -3,750 & 0,000 \\ 0,067 & 0,043 & 1,560 & 0,118 \\ -0,147 & 0,063 & -2,320 & 0,021 \\ -0,225 & 0,063 & -3,590 & 0,000 \\ -0,549 & 0,079 & -6,980 & 0,000 \\ -0,048 & 0,050 & -0,950 & 0,344 \\ 0,007 & 0,057 & 0,130 & 0,899 \\ 0,135 & 0,046 & 2,940 & 0,003 \\ -0,363 & 0,099 & -3,680 & 0,000 \\ -0,396 & 0,090 & -4,420 & 0,000 \\ -0,202 & 0,082 & -2,460 & 0,014 \\ 0,086 & 0,059 & 1,460 & 0,143 \\ -0,023 & 0,075 & -0,310 & 0,757 \\ 0,004 & 0,059 & 0,070 & 0,948 \\ 0,391 & 0,124 & 3,150 & 0,002 \\ 0,295 & 0,059 & 5,020 & 0,000 \\ 0,403 & 0,065 & 6,240 & 0,000 \\ 0,564 & 0,068 & 8,350 & 0,000 \\ -1,022 & 0,116 & -8,840 & 0,000\end{array}$

Buying equation

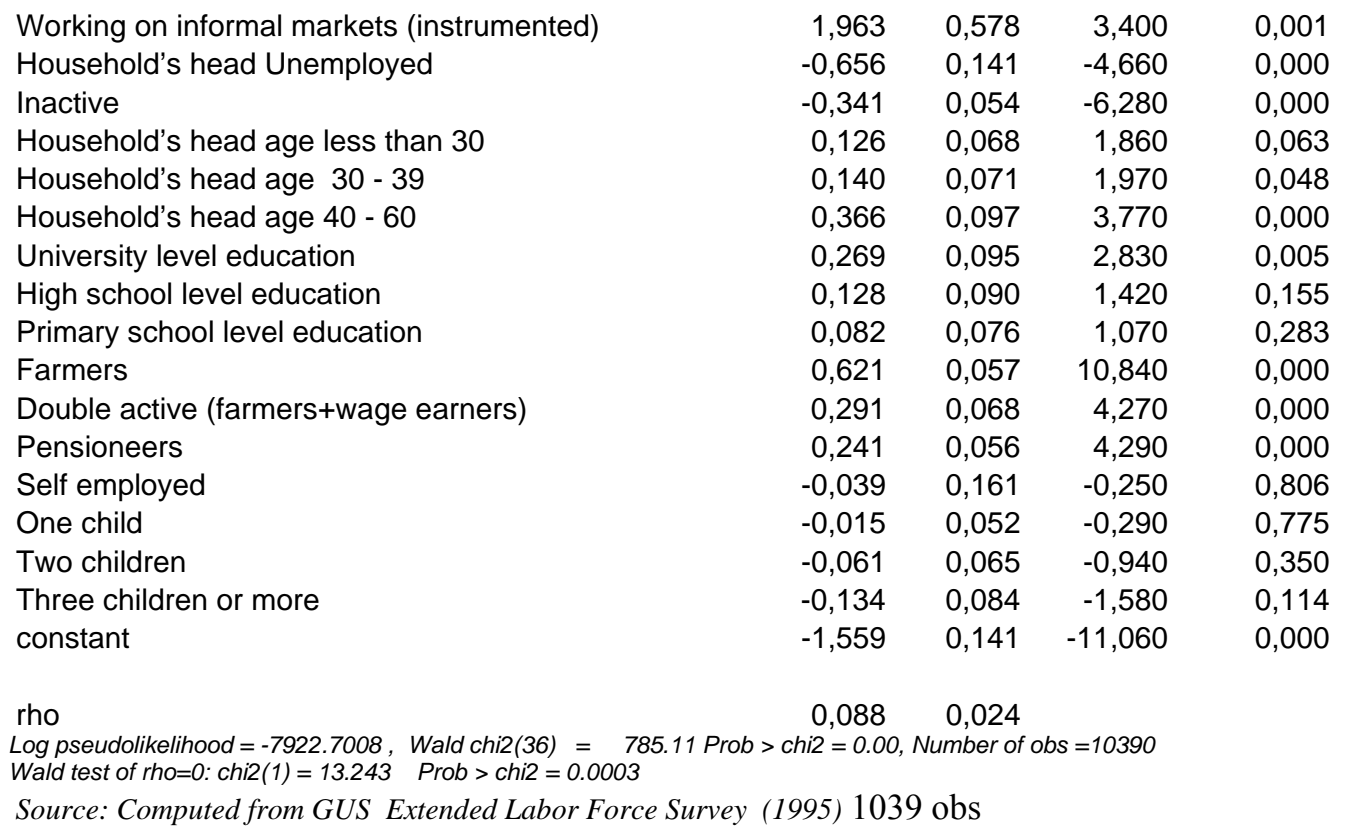


Probability of buying and working on informal markets Recursive bivariate probit model

marginal effects*

variable

dy/dx Std, Err, Average

Working on informal markets

(instrumented)

Household's head

Unemployed

$0,451 \quad 0,133 \quad 0,123$

Inactive

$\begin{array}{lll}-0,106 & 0,014 & 0,038\end{array}$

Household's head age less

than 30

$-0,075 \quad 0,011 \quad 0,361$

Household's head age $30-39$

$0,030 \quad 0,017 \quad 0,210$

Household's head age 40 - 60

$0,033 \quad 0,017 \quad 0,416$

University level education

$0,091 \quad 0,026 \quad 0,295$

High school level education

$0,068 \quad 0,026 \quad 0,114$

$0,030 \quad 0,022 \quad 0,245$

Primary school level education $\quad 0,019 \quad 0,017 \quad 0,589$

Farmers

$0,179 \quad 0,020 \quad 0,090$

Double active (farmers+wage

earners)

$0,076 \quad 0,020 \quad 0,046$

Pensioneers

$0,057 \quad 0,014 \quad 0,364$

Self employed

$-0,009 \quad 0,035$

0,015

One child

$-0,003 \quad 0,012 \quad 0,437$

Two children

$-0,014 \quad 0,014$

0,214

Three children or more

$-0,029 \quad 0,018$

0,183

$y=\operatorname{Pr}($ achat $=1)$ (predict, pmarg) $=0,147, d y / d x$ is for discrete change of dummy variable from 0 to 1 at the average point, Number of obs $=10390$ Source: Computed from GUS Extended Labor Force Survey (1995), 10390 obs. 
Table B3

Probability of buying and hiring on informal markets

Recursive bivariate probit model

variable

Hiring equation

Household's head Unemployed

Inactive

$-1,180$

$\begin{array}{llll} & \text { Robust Std, } & & \\ \text { Coef, } & \text { Error } & \mathrm{z} & \mathrm{P}>|\mathrm{z}|\end{array}$

Local unemployment below the national

average.

Local unemployment above the national

average

Household's head age less than 30

Household's head age 30 - 39

Household's head age $40-60$

City 20000-99999 inhabitants

City below 20000 inhabitants

Countryside

University level education

High school level education

Primary school level education

Farmers

Double active (farmers+wage earners)

Pensioneers

One child

Two children

Three children or more

constant

$\begin{array}{rrrr}-0,823 & 0,247 & -3,340 & 0,001 \\ -1,180 & 0,097 & -12,170 & 0,000 \\ 0,141 & 0,048 & 2,940 & 0,003 \\ & & & \\ 0,056 & 0,053 & 1,070 & 0,286 \\ -0,026 & 0,085 & -0,310 & 0,754 \\ -0,002 & 0,084 & -0,020 & 0,985 \\ 0,318 & 0,105 & 3,030 & 0,002 \\ 0,222 & 0,100 & 2,230 & 0,026 \\ 0,462 & 0,100 & 4,600 & 0,000 \\ 0,741 & 0,082 & 9,040 & 0,000 \\ -0,216 & 0,131 & -1,650 & 0,099 \\ -0,261 & 0,111 & -2,360 & 0,018 \\ -0,169 & 0,098 & -1,730 & 0,084 \\ 1,092 & 0,061 & 17,880 & 0,000 \\ 0,499 & 0,076 & 6,560 & 0,000 \\ 0,402 & 0,091 & 4,410 & 0,000 \\ 0,299 & 0,078 & 3,840 & 0,000 \\ 0,421 & 0,085 & 4,940 & 0,000 \\ 0,298 & 0,091 & 3,280 & 0,001 \\ -2,334 & 0,159 & -14,680 & 0,000\end{array}$

Buying equation |

Hiring on informal markets (instrumented) |

2,165

0,354

6,120

0,000

Household's head Unemployed

$-0,214$

0,103

$-2,090$

0,037

Inactive

$-0,085$

0,067

$-1,270$

0,205

Household's head age less than 30

0,076

0,066

1,160

0,245

Household's head age $30-39$

0,056

0,065

0,860

0,388

0,094

0,077

1,220

0,224

University level education

0,221

0,088

2,510

0,012

High school level education

0,066

0,082

0,800

0,422

0,044

0,075

0,580

0,559

Farmers

$-0,045$

0,132

$-0,340$

0,734

Double active (farmers+wage earners)

$-0,040$

0,089

$-0,450$

0,655

0,094

0,059

1,600

0,110

One child

0,017

0,048

0,350

0,729

$-0,025$

0,056

$-0,450$

0,654

Three children or more

0,059

0,200

0,842

$-1,335$

0,104

$-12,860$

0,000

rho

0,764

0,016

Log pseudolikelihood $=-5601.4322$, Wald chi2(34) $=1329.77$ Prob $>$ chi2 $=.0000$ Wald test of $r$ ho $=0:$ chi2(1) $=712.593$ Prob $>$ chi $2=0.0000$, Number of obs $=10390$

Source: Computed from GUS Extended Labor Force Survey (1995,) 10390 observations 
Probability of buying and hiring on informal markets

Recursive bivariate probit model

marginal effects*

variable

Hiring on informal markets

(instrumented)

Household's head Unemployed

Inactive

Household's head age less than 30

Household's head age $30-39$

Household's head age 40 - 60

University level education

High school level education

Primary school level education

Farmers

Double active (farmers+wage earners)

Pensioneers

One child

Two children

Three children or more

$y=\operatorname{Pr}($ achat $=1)$ (predict, pmarg $)=0,147, d y / d x$ is for discrete change of dummy variable dy/dx Std, Err, Average

$0,499 \quad 0,082 \quad 0,073$

$\begin{array}{lll}-0,044 & 0,019 & 0,033\end{array}$

$-0,019 \quad 0,015 \quad 0,358$

$0,018 \quad 0,016 \quad 0,210$

$0,013 \quad 0,015 \quad 0,417$

$0,022 \quad 0,019 \quad 0,298$

$0,056 \quad 0,024 \quad 0,115$

$0,015 \quad 0,020 \quad 0,245$

$0,010 \quad 0,017 \quad 0,589$

$\begin{array}{lll}-0,010 & 0,029 & 0,091\end{array}$

$\begin{array}{lll}-0,009 & 0,020 & 0,047\end{array}$

$0,022 \quad 0,014 \quad 0,369$

$0,004 \quad 0,011 \quad 0,438$

$-0,006 \quad 0,013 \quad 0,216$

$\begin{array}{rrr}-0,006 & 0,013 & 0,216 \\ 0,003 & 0,014 & 0,185\end{array}$ from 0 to 1 at the average point, Number of obs $=10390$

Source: Computed from GUS Extended Labor Force Survey (1995) 
Table B4

Probability of working or hiring versus buying on informal markets

Recursive bivariate probit model

variable

Working or hiring equation

Household's head unemployed

Inactive

Local unemployment below the national average.

Local unemployment above the national average

Household's head age less than 30

Household's head age $30-39$

Household's head age $40-60$

City 20000-99999 inhabitants

City below 20000 inhabitants

Countryside

University level education

High school level education

Primary school level education

Farmers

Double active (farmers+wage earners)

Pensioneers

Self employed

One child

Two children

Three children or more

constant

Buying equation

\section{Hiring or working}

Household's head Unemployed

Inactive

Household's head age less than 30

Household's head age 30 - 39

Household's head age 40 - 60

University level education

High school level education

Primary school level education

Farmers

Double active (farmers+wage earners)

Pensioneers

Self employed

One child

Two children

Three children or more

constant |

rho |

Log pseudolikelihood $=-8403.3828$, Prob $>$ chi2 $=0.0000$, wald chi2 $(36)=1123$

Wald test of rho=0:chi2(1) $=396.875$, Prob $>$ chi2 $=0.0000$, Number of obs $=10390$

Source: Computed from GUS Extended Labor Force Survey (1995)
Robust

\begin{tabular}{rrrr} 
Coef, & \multicolumn{3}{c}{$P>|z|$} \\
0,356 & 0,072 & 4,910 & 0,000 \\
$-0,390$ & 0,057 & $-6,890$ & 0,000 \\
$-0,091$ & 0,035 & $-2,590$ & 0,010 \\
0,057 & 0,040 & 1,450 & 0,148 \\
$-0,104$ & 0,061 & $-1,700$ & 0,088 \\
$-0,161$ & 0,060 & $-2,660$ & 0,008 \\
$-0,261$ & 0,075 & $-3,490$ & 0,000 \\
0,006 & 0,048 & 0,130 & 0,900 \\
0,121 & 0,054 & 2,240 & 0,025 \\
0,309 & 0,043 & 7,180 & 0,000 \\
$-0,371$ & 0,089 & $-4,180$ & 0,000 \\
$-0,416$ & 0,080 & $-5,210$ & 0,000 \\
$-0,205$ & 0,073 & $-2,830$ & 0,005 \\
0,664 & 0,054 & 12,390 & 0,000 \\
0,233 & 0,068 & 3,440 & 0,001 \\
0,133 & 0,057 & 2,310 & 0,021 \\
0,508 & 0,125 & 4,060 & 0,000 \\
0,336 & 0,054 & 6,240 & 0,000 \\
0,471 & 0,059 & 8,010 & 0,000 \\
0,562 & 0,062 & 9,010 & 0,000 \\
$-1,041$ & 0,106 & $-9,850$ & 0,000
\end{tabular}

$\begin{array}{rrrr}2,101 & 0,388 & 5,410 & 0,000 \\ -0,547 & 0,111 & -4,930 & 0,000 \\ -0,116 & 0,064 & -1,820 & 0,068 \\ 0,120 & 0,066 & 1,820 & 0,068 \\ 0,138 & 0,067 & 2,070 & 0,039 \\ 0,286 & 0,079 & 3,610 & 0,000 \\ 0,363 & 0,096 & 3,770 & 0,000 \\ 0,216 & 0,091 & 2,380 & 0,018 \\ 0,114 & 0,077 & 1,490 & 0,137 \\ 0,090 & 0,123 & 0,730 & 0,463 \\ 0,053 & 0,080 & 0,660 & 0,511 \\ 0,125 & 0,057 & 2,170 & 0,030 \\ -0,143 & 0,158 & -0,910 & 0,364 \\ -0,055 & 0,052 & -1,060 & 0,288 \\ -0,134 & 0,066 & -2,030 & 0,042 \\ -0,189 & 0,077 & -2,450 & 0,014 \\ -1,654 & 0,130 & -12,700 & 0,000\end{array}$


Probability of working or hiring and buying on informal markets Recursive bivariate probit model

$$
\text { marginal effects* }
$$

\begin{tabular}{|c|c|c|c|}
\hline variable & $\mathrm{dy} / \mathrm{dx}$ & Std. Err. & Average \\
\hline Working or hiring & 0,484 & 0,089 & 0,179 \\
\hline Household's head Unemployed & $-0,095$ & 0,013 & 0,038 \\
\hline Inactive & $-0,026$ & 0,014 & 0,361 \\
\hline Household's head age less than & & & \\
\hline $\begin{array}{l}30 \\
\text { Household's head age } 30-39\end{array}$ & $\begin{array}{l}0,029 \\
0,032\end{array}$ & $\begin{array}{l}0,016 \\
0.016\end{array}$ & $\begin{array}{l}0,448 \\
0,240\end{array}$ \\
\hline Household's head age $40-60$ & 0,070 & 0,020 & 0,210 \\
\hline University level education & 0,096 & 0,029 & 0,416 \\
\hline High school level education & 0,053 & 0,023 & 0,295 \\
\hline Primary school level education & 0,026 & 0,017 & 0,206 \\
\hline Farmers & 0,022 & 0,031 & 0,126 \\
\hline $\begin{array}{l}\text { Double active (farmers+wage } \\
\text { earners) }\end{array}$ & 0,013 & 0,019 & 0,372 \\
\hline Pensioneers & 0,029 & 0,014 & 0,114 \\
\hline Self employed & $-0,031$ & 0,031 & 0,245 \\
\hline One child & $-0,013$ & 0,012 & 0,589 \\
\hline Two children & $-0,030$ & 0,014 & 0,090 \\
\hline Three children or more & $-0,041$ & 0,016 & 0,046 \\
\hline
\end{tabular}

$y=\operatorname{Pr}($ achat $=1)$ (predict, pmarg) $=0,147, d y / d x$ is for discrete change of dummy variable from 0 to 1 at the average point, Number of obs $=10390$

Source: Computed from GUS Extended Labor Force Survey (1995) 
Table B 5

Panel AIDS (system) estimates of the change in budget shares for the probability of participation in informal markets

\begin{tabular}{|c|c|c|c|c|}
\hline \multirow[t]{3}{*}{ Food } & 0.6035 & B & $\begin{array}{l}0.19772 \\
(2.7542)\end{array}$ & \\
\hline & 0.70354 & $\mathrm{~W}$ & $\begin{array}{l}0.216550 \\
(15.43)\end{array}$ & \\
\hline & 0.8663 & QGLS & $\begin{array}{l}0.19392 \\
(2.9178)\end{array}$ & 282.90317 \\
\hline \multirow[t]{3}{*}{ Alcohol and tobacco } & 1.0814 & B & $\begin{array}{l}0.03736 \\
(1.74516)\end{array}$ & \\
\hline & 0.6554 & $\mathrm{~W}$ & $\begin{array}{l}0.0102 \\
(2.69)\end{array}$ & \\
\hline & 1.1336 & QGLS & $\begin{array}{l}0.038445 \\
(1.99720)\end{array}$ & 68.213459 \\
\hline \multirow[t]{3}{*}{ Clothing } & 1.0719 & $\mathrm{~B}$ & $\begin{array}{l}-0.05575 \\
(1.48440)\end{array}$ & \\
\hline & 1.19621 & W & $\begin{array}{l}0.00281 \\
(4.06)\end{array}$ & \\
\hline & 1.1513 & QGLS & $\begin{array}{l}-0.05221 \\
(1.53260)\end{array}$ & 104.66421 \\
\hline \multirow[t]{3}{*}{ Dwelling charges) } & 0.7847 & $\mathrm{~B}$ & $\begin{array}{l}-0.05002 \\
(0.8158)\end{array}$ & \\
\hline & 0.90667 & W & $\begin{array}{l}-0.0205 \\
(-18,07)\end{array}$ & \\
\hline & 0.8645 & QGLS & $\begin{array}{l}-0.03783 \\
(0.6985)\end{array}$ & 69.384424 \\
\hline \multirow[t]{3}{*}{ Dwelling (equip) } & 2.1186 & B & $\begin{array}{l}-0.01947 \\
(0.67645)\end{array}$ & \\
\hline & 2.348 & $\mathrm{~W}$ & $\begin{array}{l}0.0046 \\
(0.81)\end{array}$ & \\
\hline & 1.4644 & QGLS & $\begin{array}{l}-0.030226 \\
(1.21118)\end{array}$ & 96.776936 \\
\hline \multirow[t]{3}{*}{ Health } & 1.055 & $\mathrm{~B}$ & $\begin{array}{l}-0.09882 \\
(4.10473)\end{array}$ & \\
\hline & 1.1525 & W & $\begin{array}{l}-0.0339 \\
(-7.29)\end{array}$ & \\
\hline & 1.006 & QGLS & $\begin{array}{l}-0.10067 \\
(4.91130)\end{array}$ & 69.719117 \\
\hline \multirow[t]{3}{*}{ Hygiene } & 1.0370 & $\mathrm{~B}$ & $\begin{array}{l}0.009655 \\
(0.85566)\end{array}$ & \\
\hline & 0.8222 & $\mathrm{~W}$ & $\begin{array}{l}-0.0107 \\
(4.87)\end{array}$ & \\
\hline & 0.8925 & QGLS & $\begin{array}{l}0.008448 \\
(0.85041)\end{array}$ & 42.117644 \\
\hline \multirow[t]{3}{*}{ Education } & 1.1159 & $\mathrm{~B}$ & $\begin{array}{l}-0.01160 \\
(0.60331\end{array}$ & \\
\hline & 0.99828 & $\mathrm{~W}$ & $\begin{array}{l}0.0109 \\
(3.17)\end{array}$ & \\
\hline & 0.6575 & QGLS & -0.004322 & 105.40015 \\
\hline
\end{tabular}


Culture

$(-0.24917)$

$1.7616 \quad$ B $\quad-0.15015$

(4.6641)

\begin{tabular}{|c|c|c|c|c|}
\hline \multirow{5}{*}{ Transp. \&com. } & 1.312 & W & $\begin{array}{l}-0.0525 \\
(-8.41)\end{array}$ & \multirow{4}{*}{89.267688} \\
\hline & 1.1516 & QGLS & $\begin{array}{l}-0.13177 \\
(4.3626)\end{array}$ & \\
\hline & 1.9853 & B & $\begin{array}{l}0.10087 \\
(2.6459)\end{array}$ & \\
\hline & 1.81 & W & $\begin{array}{l}0.0259 \\
(3.36)\end{array}$ & \\
\hline & 2.822 & QGLS & $\begin{array}{l}0.06490 \\
(1.6998)\end{array}$ & 675.89938 \\
\hline
\end{tabular}

$\mathrm{B}=$ between estimates, $W=$ within estimates, $Q G L S=$ Quasi Generalized Least Squares estimates 1.Student (robust) statistics in parenthesis

2.Income instrumented by total expenditure and socio-demographic variables.

3.Income elasticities computed at the average level of budget share

Source: Computed from GUS Household Budget panel (1994-1995) (4809 observation per year) 
Table B6

Total Expenditure Elasticities

Panel QAIDS (system) estimates

\begin{tabular}{|c|c|c|c|c|c|c|}
\hline & $\begin{array}{c}\text { Participation } \\
\text { coefficient }\end{array}$ & $\begin{array}{c}\text { Non- } \\
\text { participants }\end{array}$ & $\begin{array}{l}\text { Partici } \\
\text { pants }\end{array}$ & $\begin{array}{l}\text { Participation } \\
\text { coefficient }\end{array}$ & $\begin{array}{c}\text { Non- } \\
\text { participant } \\
\text { s }\end{array}$ & $\begin{array}{l}\text { Partici } \\
\text { pants }\end{array}$ \\
\hline & \multicolumn{3}{|c|}{ "between estimates" } & \multicolumn{3}{|c|}{ "within estimates" } \\
\hline Food & $\begin{array}{c}-0.011 \\
(.054)\end{array}$ & $\begin{array}{l}0.604 \\
(.020)\end{array}$ & $\begin{array}{l}0.683 \\
(.067)\end{array}$ & $\begin{array}{c}-0.2 \times 10^{-1} \\
\left(5 \times 10^{-7}\right)\end{array}$ & $\begin{array}{l}0.490 \\
(.0271)\end{array}$ & $\begin{array}{l}0.307 \\
(.083)\end{array}$ \\
\hline $\begin{array}{l}\text { Alcohol + } \\
\text { tobacco }\end{array}$ & $\begin{array}{l}0.030 \\
(.017)\end{array}$ & $\begin{array}{l}0.999 \\
(.006)\end{array}$ & $\begin{array}{l}0.992 \\
(.021)\end{array}$ & ns & $\begin{array}{l}0.401 \\
(.090)\end{array}$ & $\begin{array}{c}-0.099 \\
(.285)\end{array}$ \\
\hline Clothing & $\begin{array}{c}-0.019 \\
(.028)\end{array}$ & $\begin{array}{l}1.397 \\
(.059)\end{array}$ & $\begin{array}{l}0.967 \\
(.209)\end{array}$ & ns & $\begin{array}{l}1.058 \\
(.091)\end{array}$ & $\begin{array}{l}1.911 \\
(.279)\end{array}$ \\
\hline $\begin{array}{l}\text { Dwelling } \\
\text { (charges) }\end{array}$ & $\begin{array}{c}-0.033 \\
(.047)\end{array}$ & $\begin{array}{l}0.890 \\
(.040) \\
\end{array}$ & $\begin{array}{l}1.352 \\
(.188) \\
\end{array}$ & ns & $\begin{array}{l}1.300 \\
(.059)\end{array}$ & $\begin{array}{l}1.414 \\
(.244)\end{array}$ \\
\hline $\begin{array}{l}\text { Dwelling } \\
\text { (equipment) }\end{array}$ & $\begin{array}{c}0.66 \times 10^{-4} \\
(.023)\end{array}$ & $\begin{array}{l}1.871 \\
(.059) \\
\end{array}$ & $\begin{array}{c}1.256 \\
(.319)\end{array}$ & ns & $\begin{array}{c}2.160 \\
(.147)\end{array}$ & $\begin{array}{c}2.249 \\
(.386)\end{array}$ \\
\hline $\begin{array}{l}\text { Transport and } \\
\text { com. }\end{array}$ & $\begin{array}{l}0.94 \\
(.031) \\
\end{array}$ & $\begin{array}{l}1.597 \\
(.051) \\
\end{array}$ & $\begin{array}{c}1.843 \\
(.175) \\
\end{array}$ & ns & $\begin{array}{l}1.594 \\
(.077) \\
\end{array}$ & $\begin{array}{c}2.124 \\
(.232) \\
\end{array}$ \\
\hline Health & $\begin{array}{l}-0.020 \\
(.022)\end{array}$ & $\begin{array}{l}1.145 \\
(.049)\end{array}$ & $\begin{array}{l}1.019 \\
(.223)\end{array}$ & ns & $\begin{array}{l}1.266 \\
(.071)\end{array}$ & $\begin{array}{l}0.948 \\
(.284)\end{array}$ \\
\hline $\begin{array}{l}\text { Culture } \\
\text { Education }\end{array}$ & $\begin{array}{c}-0.047 \\
(.020) \\
\end{array}$ & $\begin{array}{l}0.897 \\
(.039) \\
\end{array}$ & $\begin{array}{c}0.881 \\
(.206) \\
\end{array}$ & ns & $\begin{array}{l}0.955 \\
(.042) \\
\end{array}$ & $\begin{array}{l}1.011 \\
(.231) \\
\end{array}$ \\
\hline Miscellaneous & $\begin{array}{l}0.028 \\
(.017)\end{array}$ & $\begin{array}{l}1.757 \\
(.102)\end{array}$ & $\begin{array}{c}2.306 \\
(.350)\end{array}$ & $\begin{array}{l}-0.8 \times 10^{-8} \\
\left(.75 \times 10^{-8}\right)\end{array}$ & $\begin{array}{l}2.164 \\
(.158)\end{array}$ & $\begin{array}{c}1.454 \\
(.420)\end{array}$ \\
\hline
\end{tabular}

\section{Notes:}

Qaids Specification: $w_{\text {iht }}=\alpha_{i}+\Sigma_{j} \gamma_{i j} \ln p_{j t}+\beta_{i} \ln \left[m_{h t} / a\left(p_{t}\right)\right]+\left\{\left[\lambda_{i} / b\left(p_{t}\right)\right] \ln [m / a(p)]\right\}^{2}+W_{h t} \cdot \gamma_{i}+u_{i h t}$ with $\ln a\left(p_{t}\right)=\alpha_{0}+\Sigma_{j} \alpha_{i} \ln p_{i t}+0.5$

$\Sigma_{\mathrm{i}} \Sigma_{\mathrm{j}} \gamma_{\mathrm{ij}} \ln \mathrm{p}_{\mathrm{it}} \cdot \ln \mathrm{p}_{\mathrm{it}}$ and $\mathrm{b}\left(\mathrm{p}_{\mathrm{t}}\right)=\Pi_{\mathrm{i}} \mathrm{p}_{\mathrm{it}}{ }^{\beta}$

Logarithm of total Expenditures instrumented.

Other determinants : logarithmic age of the head, proportion of children in the family, relative logarithmic prices, education and location dummies, quarter dummies for each year. The true price index is approximated by a Stone price index.

Estimation Method : by convergence, $75_{\text {th }}$ iteration estimated on pooled cross-sections, on the integrability parameter $\mathrm{b}(\mathrm{p})$. Additivity constrained.

Ns : Not significant

Source: Computed from GUS Household Budget panel (1994-1995) (4809 observation per year) 